\title{
Upconversion of Cellulosic Waste Into a Potential "Drop in Fuel" via Novel Catalyst Generated Using Desulfovibrio desulfuricans and a Consortium of Acidophilic Sulfidogens
}

OPEN ACCESS

Edited by:

Kirk T. Semple,

Lancaster Environment Centre,

Lancaster University, United Kingdom

Reviewed by:

Amy Michele Grunden,

North Carolina State University,

United States

Eric D. van Hullebusch,

UMR7154 Institut de Physique du

Globe de Paris (IPGP), France

*Correspondence:

Lynne E. Macaskie

L.E.Macaskie@bham.ac.uk

${ }^{\dagger}$ Joint first authors

Specialty section:

This article was submitted to

Microbiological Chemistry

and Geomicrobiology,

a section of the journal

Frontiers in Microbiology

Received: 18 December 2018 Accepted: 17 April 2019

Published: 10 May 2019

Citation:

Mikheenko IP, Gomez-Bolivar J, Merroun ML, Macaskie LE, Sharma S,

Walker M, Hand RA, Grail BM,

Johnson DB and Orozco RL (2019)

Upconversion of Cellulosic Waste Into

a Potential "Drop in Fuel" via Novel

Catalyst Generated Using

Desulfovibrio desulfuricans

and a Consortium of Acidophilic

Sulfidogens. Front. Microbiol. 10:970.

doi: 10.3389/fmicb.2019.00970
Iryna P. Mikheenko'1t, Jaime Gomez-Bolivar2t, Mohamed L. Merroun², Lynne E. Macaskie ${ }^{1 *}$, Surbhi Sharma ${ }^{1}$, Marc Walker $^{3}$, Rachel A. Hand ${ }^{4}$, Barry M. Grail ${ }^{5}$, David Barrie Johnson ${ }^{5}$ and Rafael L. Orozco ${ }^{1}$

${ }^{1}$ School of Biosciences, University of Birmingham, Birmingham, United Kingdom, ${ }^{2}$ Department of Microbiology, Faculty of Sciences, University of Granada, Granada, Spain, ${ }^{3}$ Department of Physics, University of Warwick, Coventry, United Kingdom, ${ }^{4}$ Department of Chemistry, University of Warwick, Coventry, United Kingdom, ${ }^{5}$ School of Natural Sciences, Bangor University, Gwynedd, United Kingdom

Biogas-energy is marginally profitable against the "parasitic" energy demands of processing biomass. Biogas involves microbial fermentation of feedstock hydrolyzate generated enzymatically or thermochemically. The latter also produces 5-hydroxymethyl furfural (5-HMF) which can be catalytically upgraded to 2, 5-dimethyl furan (DMF), a "drop in fuel." An integrated process is proposed with side-stream upgrading into DMF to mitigate the "parasitic" energy demand. 5-HMF was upgraded using bacteriallysupported Pd/Ru catalysts. Purpose-growth of bacteria adds additional process costs; $\mathrm{Pd} / \mathrm{Ru}$ catalysts biofabricated using the sulfate-reducing bacterium (SRB) Desulfovibrio desulfuricans were compared to those generated from a waste consortium of acidophilic sulfidogens (CAS). Methyl tetrahydrofuran (MTHF) was used as the extraction-reaction solvent to compare the use of bio-metallic $\mathrm{Pd} / \mathrm{Ru}$ catalysts to upgrade $5-\mathrm{HMF}$ to DMF from starch and cellulose hydrolyzates. MTHF extracted up to $65 \%$ of the 5HMF, delivering solutions, respectively, containing 8.8 and $2.2 \mathrm{~g} \mathrm{5-HMF/L} \mathrm{MTHF.}$ Commercial 5\% (wt/wt) Ru-carbon catalyst upgraded 5-HMF from pure solution but it was ineffective against the hydrolyzates. Both types of bacterial catalyst (5wt\%Pd/3$5 w t \% R u$ ) achieved this, bio-Pd/Ru on the CAS delivering the highest conversion yields. The yield of 5-HMF from starch-cellulose thermal treatment to 2,5 DMF was 224 and $127 \mathrm{~g} \mathrm{DMF} / \mathrm{kg}$ extracted 5-HMF, respectively, for CAS and D. desulfuricans catalysts, which would provide additional energy of 2.1 and $1.2 \mathrm{kWh} / \mathrm{kg}$ extracted $5-\mathrm{HMF}$. The CAS comprised a mixed population with three patterns of metallic nanoparticle (NP) deposition. Types I and II showed cell surface-localization of the $\mathrm{Pd} / \mathrm{Ru}$ while type III localized NPs throughout the cell surface and cytoplasm. No metallic patterning in the NPs was shown via elemental mapping using energy dispersive $\mathrm{X}$-ray microanalysis 
but co-localization with sulfur was observed. Analysis of the cell surfaces of the bulk populations by X-ray photoelectron spectroscopy confirmed the higher $S$ content of the CAS bacteria as compared to $D$. desulfuricans and also the presence of $\mathrm{Pd}-\mathrm{S}$ as well as Ru-S compounds and hence a mixed deposit of $\mathrm{PdS}, \mathrm{Pd}(0)$, and $\mathrm{Ru}$ in the form of various $+3,+4$, and +6 oxidation states. The results are discussed in the context of recently-reported controlled palladium sulfide ensembles for an improved hydrogenation catalyst.

Keywords: 5-hydroxymethylfurfural upgrade, 5-HMF upgrade, PdRu catalyst, Desulfovibrio desulfuricans, waste sulfidogenic bacteria

\section{INTRODUCTION}

The climatic impact of atmospheric $\mathrm{CO}_{2}$, a legacy of the use of fossil fuels, is now accepted and stricter worldwide environmental legislation has promoted global interest in developing carbonneutral fuels from biomass (Chu and Majumdar, 2012; AlAmin et al., 2015; Cadez and Czerny, 2016), consistent with increasing value creation from natural resources (e.g., renewable biomass) within the concept of a circular economy (Govindan and Hasanagic, 2018).

Biomass sources include wood, plants, agricultural and energy crops, aquatic plants and food processing wastes, e.g., stems and husks. Although biomass-derived fuels offer a renewable and sustainable potential alternative to fossil fuels biomass conversion technologies are usually needed. These are generally grouped into two categories: biochemical and thermochemical. The former depends on the relatively slow action of microorganisms and/or enzymatic catalysts at moderate temperatures (e.g., up to $\sim 60^{\circ} \mathrm{C}$ ) which usually follow a mechanical, thermal or chemical pretreatment of the native biomass (Modenbach and Nokes, 2013; Haldar et al., 2016). The latter require high temperatures and pressures (e.g., $200-375^{\circ} \mathrm{C}$ and $40-220$ bar, respectively) with or without the presence of metallic/inorganic-catalysts to obtain products from different biomass sources (Gollakota et al., 2018) in a matter of hours. Less aggressive methods such as the Hydro Thermal Hydrolysis (HTH) processes (e.g., Dogaris et al., 2009; Vardon et al., 2012) provide a route for wet biomass (e.g., algae Kunwar et al., 2017) conversion, forestalling the energy demand of drying. The process uses water as the reaction solvent, this being compatible with downstream fermentation of the product.

Starch and cellulose are the predominant polymeric materials in biomass. Depending on the reaction conditions their HTH generates hydrolyzates containing mainly sugars (e.g., glucose, fructose) for onward fermentation into gaseous fuels, significant amounts of 5-hydroxymethylfurfural (5-HMF; a fermentation inhibitor), and smaller amounts of other sub-products resulting from further degradation of 5-HMF during the reaction (Palmqvist and Hahn-Hägerdal, 2000). The sugars are readily fermented (e.g., to make biohydrogen) following toxic 5-HMF removal (Orozco, 2012; Redwood et al., 2012), however, at the same time the latter co-product can provide a potential resource in parallel to the primary fermentation process.

5 -HMF is a versatile platform chemical that offers potential pathways to the synthesis of valuable products including polymers, fine chemicals and biofuels (Yang et al., 2017). Hence it is important to explore and evaluate these routes to mitigate the shortfall of the HTH process economics mainly attributed to the high-heat requirement (Gollakota et al., 2018) for the thermochemical biomass processing, as well as the high power demand of biomass comminution upstream. For example the energy consumption to mill Miscanthus (moisture content of $15 \%$ ) to $4 \mathrm{~mm}$ was determined at $184 \mathrm{~kJ} / \mathrm{kg}$ of dry matter (Miao et al., 2011). Gollakota et al. (2018) noted that an efficient algal feedstock-HTH process (@280 $\mathrm{C}, 15 \mathrm{~min}$ ) consumed $\sim 15 \%$ of the energy contained in the feedstock thereby yielding a potential energy efficiency of $\sim 85 \%$ (Gollakota et al., 2018). By using algal biomass comminution is not required. Other studies calculated an energy efficiency of $63.9 \%$ for thermal hydrolysis $\left(300^{\circ} \mathrm{C}\right)$ in a cornstalk-HTH (Shi et al., 2013).

Among the possibilities for 5-HMF conversion into valuable products 2,5 dimethylfuran (DMF) is a biofuel of particular importance due to its high energy density $(30 \mathrm{MJ} / \mathrm{L}$ ) (similar to gasoline: $31.9 \mathrm{MJ} / \mathrm{L}$ ), its high octane number, low oxygen content $(\mathrm{O} / \mathrm{C}$ 0.17), its immiscibility with water and its affinity to blend with fossil-derived fuels and ethanol (Roman-Leshkov et al., 2007; Thananatthanachon and Rauchfuss, 2010; Zhang et al., 2017) as well as its proven use in a direct-injection spark-ignition engine (Dang et al., 2016). DMF is not water soluble, has a boiling point of $92-96^{\circ} \mathrm{C}$ and its evaporation requires approximately one-third less energy than the evaporation of ethanol (Da Silva and Aznar, 2014) which is widely used as a biofuel despite the energy demand of distillation.

The catalytic upgrading of 5-HMF to DMF, proposed as a route to making liquid fuel from carbohydrates (Roman-Leshkov et al., 2007) proceeds in the absence of water as the latter negatively impacts in the hydrogenation reactions, decreasing yields and selectivity (Liu et al., 2015). HTH is performed in an aqueous system, hence an ideal method would both separate the 5-HMF from the fermentable aqueous phase (detoxifying it) and maximize its catalytic upgrading to DMF. The separation of 5-HMF from the hydrolysis products in the aqueous phase is a challenge that must be overcome in order to detoxify the fermentation stream and valorize the 5-HMF component into local power, with the extraction and catalytic upgrading steps in a common solvent. The selection and evaluation of solvent for this dual role was the first aim of the study, considering two main factors: The 5-HMF-solvent partition coefficient $\left(\mathrm{P}_{\mathrm{HMF}}\right.$ $\left.\left[\mathrm{wt} \% \mathrm{org}_{\mathrm{og}} / \mathrm{wt} \%_{\mathrm{aq}}\right]\right)$ and the solvent compatibility with the catalytic 
upgrading reactions. Partition coefficient $\left(\mathrm{P}_{\mathrm{HMF}}\right)$ quantifies the equilibrium distribution of a solute between 2 immiscible phases and is a measure for solvent extraction efficiency. The higher the $\mathrm{P}_{\mathrm{HMF}}$ value the higher the extraction efficiency.

Tetrahydrofuran (THF) is an efficient solvent for the catalytic transformation of 5-HMF to DMF in the presence of ruthenium catalysts, delivering DMF yields up to 95\% (Hu et al., 2014). However, its miscibility with water limits its application here. Methyl tetrahydrofuran (MTHF) is a solvent produced from renewable resources (Aycock, 2007) with similar properties to THF [relatively high partition coefficient $\left(\mathrm{P}_{\mathrm{HMF}}\right.$ of 2.1)] and low water solubility $(4 \mathrm{~g} / 100 \mathrm{~mL})]$. MTHF has replaced THF in several organometallic-catalyzed reactions (Aycock, 2007; Blumenthal et al., 2016). Moreover, the presence of sugars (glucose and fructose) in the hydrolyzate can enhance the extraction capacity of the MTHF and induce phase separation. For example, with the addition of 10,30 , or $50 \mathrm{wt} \%$ of fructose the partition coefficient increased by $>40-50 \%$ for MTHF (Blumenthal et al., 2016). MTHF delivers clean organicwater phase separations and, unlike THF, it can be used to dry the product for a subsequent reaction or isolation step (Aycock, 2007).

The second focus of this study is the catalytic upgrading of 5-HMF to DMF and the scope for using novel biogenic metal catalysts for this reaction. Other work reports that ruthenium catalyst can achieve this conversion (Hu et al., 2014; Lei et al., 2014; Nagpure et al., 2015). Hu et al. (2014) reported DMF yields of 95\% while Nagpure et al. (2015) showed that a catalyst containing $<0.6 \mathrm{wt} \% \mathrm{Ru}$ converted 5 -HMF to $58 \%$ yield of DMF in propanol. In parallel, Lei et al. (2014) obtained 95\% yield of DMF (in THF; $200^{\circ} \mathrm{C}$ in $2 \mathrm{~h}$ ) while the direct hydrogenation of carbohydrate-derived HMF into DMF was also achieved, with DMF separation from the reaction mixture by distillation (Lei et al., 2014).

Other studies focused on high yields and selectivity toward DMF using "classical" mono and also bimetallic catalysts, including $\mathrm{Pd}$ and $\mathrm{Ru}$ (Hansen et al., 2012; Nishimura et al., 2014; Zu et al., 2014; Luo et al., 2015; Mitra et al., 2015) as well as less conventional catalysts (Gawade et al., 2016), which include biologically-derived materials. A preliminary study using cells of Bacillus benzeovorans as the catalyst support noted that, while classical $5 \mathrm{wt} \% \mathrm{Pd}$ on carbon catalysts achieved 95\% conversion of commercial 5-HMF (yield was $25 \%$ DMF in formic acid/trimethylamine), a bimetallic biocatalyst of $2.5 \mathrm{wt} \% \mathrm{Pd} / 2.5 \mathrm{wt} \% \mathrm{Ru}$ achieved $97 \%$ conversion with $50 \%$ selectivity (Omajali, 2015). In propanol the respective DMF yields (at $94 \%$ conversion) for the chemical $\mathrm{Pd} / \mathrm{C}$ and bio- $\mathrm{Pd} / \mathrm{Ru}$ were 33 and 42\%, respectively (Omajali, 2015) but detailed studies using THF as the solvent were not undertaken. As far as the authors are aware, most studies have focused on up-conversion of commercially-obtained 5-HMF whereas this study focuses on 5-HMF within the product mix obtained from starch/cellulose thermochemical hydrolysis. A single stage reaction hydrolysis and up-conversion reaction formed the second aim of the study.

A commissioned consultancy report (Catalytic Management Technology Ltd., unpublished) noted that for a new catalyst to achieve market acceptance it must be better than commercially available comparators, or be cheaper to produce. For the latter, biogenic catalyst can be biorefined from metallic wastes into active neo-catalysts (Yong et al., 2010; Murray et al., 2017, 2019). However, growing cultures of bacteria solely for this purpose lowers the cost-effectiveness, and using "second life" bacterial cells left over from another biotechnology process has therefore been used to make active bio-metallic catalyst for a fuel cell (Orozco et al., 2010) and as a hydrogenation catalyst (Zhu et al., 2016). Therefore, the third aim of the study was to evaluate the potential using a consortium of acidophilic, sulfidogenic (CAS) bacteria left over from an unrelated biotechnology process for its ability to make bio- $\mathrm{Pd} / \mathrm{Ru}$ catalyst for upgrading of 5-HMF, and to compare this with using a pure culture of the sulfatereducing bacterium (SRB) Desulfovibrio desulfuricans, which was purpose-grown for the application.

The primary biotechnology process for the CAS uses $\mathrm{H}_{2} \mathrm{~S}$ generated in a low $\mathrm{pH}$ sulfidogenic bioreactor to selectively remove and to recover metal resources (as sulfide precipitates) from metal-rich mine water wastes (Nancucheo and Johnson, 2012; Santos and Johnson, 2017, 2018). The bioreactors are operated in continuous flow mode and generate an effluent liquor that contains both bacterial cells and some residual sulfide A full-scale system has been estimated to generate several hundred liters of waste liquor/day (Murray et al., 2019). The bacteria, like D. desulfuricans, would contain residual biogenic sulfide, usually considered as a potent catalyst poison (Dunleavy, 2006). Against this, classical sulfidogenic Desulfovibrio (washed) cells produced a bio- $\operatorname{Pd}(0)$ catalyst that was as effective as that made by (nonsulfidogenic) E. coli (Deplanche et al., 2014) and also produced a better fuel cell electrocatalyst (Yong et al., 2007). A recent study has highlighted the role of palladium sulfide modifier to a Pd catalyst which was superior in the semi hydrogenation of alkynes (Albani et al., 2018). Analysis of bio-Pd(0) on D. desulfuricans confirmed the presence of sulfur by energy dispersive X-ray microanalysis, while the outermost $\sim 10 \mathrm{~nm}$ layer of washed cells was shown to comprise $1.3 \%$ atomic concentration of sulfur as determined by X-ray photoelectron spectroscopy (Omajali, 2015); the binding energy (eV) of peak positions for S2p was shifted from 165.39 to the lower binding energy of 163.97 after addition of PdII) (Omajali, 2015), which suggests the formation of a Pd-S bond (Gotterbarm et al., 2012). Hence this study sought to compare bio-Pd/Ru from the two types of sulfidogenic culture, placing the findings in the context of what is known about the 5HMF upgrading reaction and the potential for "in process" energy generation within an integrated biorefinery and in the context of current developments in "classical" hydrogenation catalysts.

\section{MATERIALS AND METHODS}

\section{Thermo-Hydrolysis Reactions}

The method for thermal hydrolysis was as described previously (Orozco et al., 2012). The batch reactor system for starch/cellulose hydrolysis comprised a bench top reactor (100 mL; Parr series 4590 pressure; maximum operating conditions: 200 bar; $350^{\circ} \mathrm{C}$ ) of Type 316 Stainless Steel equipped with a heat/agitation controller (Parr 4848). All chemicals in the 
study were analytical grade from Sigma-Aldrich (potato starch, cellulose powder, 5-HMF and 2 methyl-tetra-hydro-furan.

For hydrolysis, starch (7.2 g) or cellulose $(5.1 \mathrm{~g})$ was suspended in de-ionized water (final reactant volume of $60 \mathrm{~mL}$ for starch; $120 \mathrm{~g} / \mathrm{L}$ and $70 \mathrm{ml}$ for cellulose; $72.9 \mathrm{~g} / \mathrm{L}$ or as otherwise stated) and charged into the reactor for hydrolysis. The reactor was sealed and purged with $\mathrm{N}_{2}$ three times before pressurizing to 30 bar $\left(\mathrm{N}_{2}\right)$ and heating to the set-point temperature $\left(220^{\circ} \mathrm{C}\right.$ for starch; $260^{\circ}$ for cellulose) with agitation (300 rpm). Reaction conditions were held for $15 \mathrm{~min}$ before cooling to $35^{\circ} \mathrm{C}$ by submersion in cold water. The hydrolyzate was separated (after depressurization) from the solid residue (vacuum filtration; filter paper Fisherbrand QL100) or by centrifugation (10,000 rpm; $10 \mathrm{~min}$ ). The reactions were repeated as required and pooled to produce sufficient quantities of starch and cellulose-derived 5HMF. Hydrolyzates were kept at $4^{\circ} \mathrm{C}$ before analysis using a GC (Shimadzu 2010 with an autosampler AOC-20S, a FID detector and ZB-Wax column $(30 \mathrm{~m} \times 0.25 \mathrm{~mm} \times 0.25 \mu \mathrm{m})$; injection volume $1 \mu \mathrm{L}$; inlet temperature $260^{\circ} \mathrm{C}$; injector temperature $300^{\circ} \mathrm{C}$; detector temperature; $300^{\circ} \mathrm{C}$, inlet pressure $100 \mathrm{KPa}$; split ratio of 100:1 with $\mathrm{H}_{2}$ carrier gas at a flow rate of $1 \mathrm{~mL} / \mathrm{min}$ ). The heating regime was $0 \mathrm{~min} \mathrm{GC}$ temp $100^{\circ} \mathrm{C} ; 10 \mathrm{~min} \mathrm{GC}$ temp $200^{\circ} \mathrm{C} ; 22 \mathrm{~min} \mathrm{GC}$ temp $200^{\circ} \mathrm{C}$ and $25 \mathrm{~min} \mathrm{GC}$ temp $250^{\circ} \mathrm{C}$. Reaction solid residues were not quantified nor analyzed.

\section{Solvent Extraction of 5-HMF}

The method for 5-HMF extraction was based on the experimental determination of partition coefficients at batch and continuous conditions according to Blumenthal et al. (2016). In this study the mass transfer of 5-HMF from the aqueous to the organic phase was faster at $60^{\circ} \mathrm{C}$ and concentrations of 5-HMF in the range between 1 and $5 \mathrm{wt} \%$ in the aqueous feed had little effect on the partition coefficients (not shown). The produced starch and cellulose hydrolyzates, respectively, were mixed in equal volumetric proportions with 2-MTHF (organic extraction solvent) in an Erlenmeyer flask [magnetic stirrer, $200 \mathrm{rpm}, 60^{\circ} \mathrm{C}$ (temperature-controlled water bath); $20 \mathrm{~min}]$. After extraction aqueous and organic phases were separated into: the top organic phase "supernatant" and the bottom aqueous phase "filtrate." Both phases were sampled and kept at $-20^{\circ} \mathrm{C}$ before analysis by GC. Solvent extraction efficiency was calculated according to Equation (1):

Extraction efficiency $(\%)=\frac{\text { moles of HMF in supernatant }}{\text { moles of HMF in hydrolysate }} * 100$

\section{Catalyst Preparation \\ Bacterial Cultures}

Desulfovibrio desulfuricans NCIMB 8307 was grown sulfidogenically as described previously (Omajali et al., 2015). Following harvest and washing $\left(9,000 \times g ; 4^{\circ} \mathrm{C}\right.$; washed three times in $20 \mathrm{mM}$ MOPS-NaOH buffer, $\mathrm{pH}$ 7.0) the cells were left at $4^{\circ} \mathrm{C}$ under nitrogen until use. The consortium of acidophilic sulfidogenic (CAS) bacteria (waste culture) was taken from a continuous metal waste treatment process with the $\mathrm{H}_{2} \mathrm{~S}$ off-gas diverted into metal sulfide recovery from minewater. Two batches of CAS $\sim 15 \mathrm{~L}$ each, were collected independently over several days, harvested, washed as for D. desulfuricans and stored as a concentrated suspension at $4^{\circ} \mathrm{C}$ under air, routinely overnight, before metallization. Using terminal restriction enzyme fragment length polymorphism (T-RFLP) analysis, as previously reported for this microbial consortium (Santos and Johnson, 2017), the CAS was found to comprise $66 \%$ Desulfosporosinus acididurans (SánchezAndrea et al., 2015) 7\% Firmicute strain CEB3, 10\% Acidocella aromatica strain PFBC, 10\% Actinobacterium AR3, and 7\% Acidithiobacillus ferrooxidans. Cells were harvested and washed as for $D$. desulfuricans and left under $\mathrm{N}_{2}$ before metallization.

\section{Preparation of Monometallic and Bimetallic Bionanoparticles}

Commercial metal salts $\left(\mathrm{NaPdCl}_{4}\right.$ and $\left.\mathrm{RuCl}_{3}\right)$ were from SigmaAldrich, as were $5 \mathrm{wt} \% \mathrm{Pd}$ and $5 \mathrm{wt} \% \mathrm{Ru}$ on carbon catalysts and commercial 5-HMF ( $\geq 99 \%)$ and 2,5-DMF (99\%). For monometallic bio-Ru catalysts cell suspensions were suspended in $1 \mathrm{mM} \mathrm{Ru}$ (III) ( $\mathrm{RuCl} 3.2 \mathrm{H}_{2} \mathrm{O}$ solution; $\mathrm{pH} 2$, in $10 \mathrm{mM} \mathrm{HNO} 3$ ) to the required biomass/metal ratio for the desired loading ( $\mathrm{wt} \%$ ) and left for $30 \mathrm{~min}\left(30^{\circ} \mathrm{C}\right)$ for metal uptake by the cells. $\mathrm{H}_{2}$ was bubbled for $\sim 1$ h through the $\mathrm{Ru}(\mathrm{III})$-cells suspension then was left under $\mathrm{H}_{2}$ (sealed bottle; $180 \mathrm{rpm}$ agitation; $30^{\circ} \mathrm{C}$ ) for $96 \mathrm{~h}$, with residual $\mathrm{Ru}(\mathrm{III})$ in solution analyzed by the tin chloride method (Charlot, 1978; Deplanche et al., 2010) to estimate the actual wt\% loading on the cells (all of the Pd was removed onto the cells in the first step).

Synthesis of bimetallic Pd/Ru used, sequentially, a $2 \mathrm{mM} \mathrm{Pd}$ (II) and a $1 \mathrm{mM} \mathrm{Ru}$ (III) solution by the method of Deplanche et al. (2012) with modifications: $2 \mathrm{mM}$ Pd (II) solution was reduced to $\mathrm{Pd}(0)$ on the cells under $\mathrm{H}_{2}$ (30 min; complete removal (by assay) of residual soluble $\mathrm{Pd}(\mathrm{II})$ ) to give $5 \mathrm{wt} \%$ bio$\mathrm{Pd}$. The bio-Pd was washed twice (distilled water) and then added to the required volume of $1 \mathrm{mM} \mathrm{RuCl}_{3}$ solution to give a final loading of (nominally) $5 \mathrm{wt} \% \mathrm{Pd} / 5 \mathrm{wt} \% \mathrm{Ru}$. The Bio$\mathrm{Pd} / \mathrm{Ru}$ mixture was left to stand $(1 \mathrm{~h})$ then saturated with $\mathrm{H}_{2}$ (as above; $180 \mathrm{rpm}$ agitation, $30^{\circ} \mathrm{C}$; $96 \mathrm{~h}$ ). Residual $\mathrm{Ru}(\mathrm{III})$ was estimated by assay (above). The presumptive bimetallic bio-NPs were washed three times (distilled water) and once with acetone $\left(9,000 \times \mathrm{g}, 15 \mathrm{~min}, 4^{\circ} \mathrm{C}\right)$ air- dried and ground manually in a pestle and mortar.

\section{Scanning Electron Microscopy (SEM), High Resolution Scanning-Transmission Electron Microscopy (STEM) With HAADF (High-Angle Annular Dark Field) Detector, Energy Dispersive X-Ray Analysis (EDX), and Determination of Lattice Spacing}

For STEM samples were fixed in glutaraldehyde $\left[2 \mathrm{~h} ; 4^{\circ} \mathrm{C} ; 2.5 \%\right.$ $(\mathrm{w} / \mathrm{v})$ in $0.1 \mathrm{M}$ cacodylate buffer, $\mathrm{pH} 7.2$ ], and, after washing (three times with the cacodylate buffer), were stained ( $1 \%$ aq. osmium tetraoxide). Thin sections were prepared for TEM as described previously (Deplanche et al., 2012), and electron opaque regions were examined by STEM and EDX using a FEI 
image Cs-corrector configuration $\operatorname{Titan}^{\mathrm{TM}}$ G2 60-300 STEM microscope equipped with HAADF detector (accelerating voltage of $300 \mathrm{kV}$ ), with lattice spacings determined using "ImageJ" through profiling of high resolution HAADF-STEM images. For examination of the CAS mixed population by scanning electron microscopy (SEM) samples were mounted on aluminum stubs using carbon adhesive tape and coated with carbon (EMITECH K975X coater). The coated samples were observed using a Quanta 400 FEIESEM operating at an accelerating voltage of $5 \mathrm{kV}$.

\section{X-Ray Photoelectron Spectroscopy (XPS) of Material at Cell Surfaces}

A few mg of samples were air-dried. XPS was used for analysis of surface chemical composition and determination of metal oxidation state (Kratos Axis Ultra DLD spectrometer; Kratos Analytical), as described by Omajali (2015), at room temperature. Illumination of samples used an $\mathrm{Al} \mathrm{K \alpha}$ x-ray source, with emitted photoelectrons collected using a hemispherical electron analyzer. Survey spectra were acquired at a pass energy of $160 \mathrm{eV}$ (resolution $\sim 2.0 \mathrm{eV}$ ), with the pass energy being reduced to $20 \mathrm{eV}$ (resolution $0.4 \mathrm{eV}$ ) for the acquisition of high resolution core level spectra. As the samples were insulating, a charge neutralizer was used to prevent surface charging with a low energy electron beam directed on to the sample during XPS data acquisition. A take-off angle of $90^{\circ}$ was used, to probe a depth of $\sim 5-10 \mathrm{~nm}$ to examine bio-NPs located at the outermost cell surfaces. Generated data were converted into VAMAS format and analyzed (CasaXPS package: Fairley, 2013) employing Shirley backgrounds, mixed Gaussian-Lorentzian (Voigt) line-shapes and asymmetry parameters where appropriate. All binding energies were calibrated to the $\mathrm{C} 1 \mathrm{~s}$ peak originating from $\mathrm{C}-\mathrm{H}$ or C-C groups at $284.8 \mathrm{eV}$. References were commercial $5 \mathrm{wt} \%$ $\mathrm{Pd}$ on carbon and commercial $\mathrm{RuCl}_{3}$.

\section{Synchrotron-Based Radiation-Scanning X-Ray Microscopy (SRSXM) Study of Elemental Pd, Ru, and Light Elements in $\mathrm{Bio}-\mathrm{Pd} / \mathrm{Ru}$}

Samples prepared as for TEM, thin-sectioned $(0.25 \mu \mathrm{m})$ using a diamond knife on a Reichert Ultracut $S$ ultramicrotome and stained as above, were examined using scanning X-ray microscopy [beamline IO8, Diamond Light Source (United Kingdom $)^{1,2}$ ] typically operating at $3 \mathrm{GeV}$ energy of the storage ring with top-up injection mode at $300 \mathrm{~mA}$ current. The IO8 beamline at Diamond uses radiation in the 0.25-4.4 keV photon energy range, generated by an Apple II-type-undulator. X-ray fluorescence (XRF) elemental mapping data were acquired for the light elements using the $\mathrm{K}$ absorption edges and acquired from $\mathrm{L}$ edges for the metallic elements. XRF data analysis was performed using the PyMCA (Phyton Multichannel Analyser) software, a multiplatform code for the analysis of the ED-XRF spectra.

${ }^{1}$ http://www.diamond.ac.uk/Beamlines/Spectroscopy/IO8.html

${ }^{2}$ https://www.diamond.ac.uk/Instruments/Imaging-and-Microscopy/I08

\section{Catalytic Upgrading of 5-HMF to 2,5-DMF}

The catalytic transfer hydrogenation reactions were carried out in a stainless steel Parr reactor series 4590 as described above. Three sets of experiments were carried out: set 1 (commercially obtained 5-HMF); set 2 (starch-derived 5-HMF) and set 3 (cellulose derived 5-HMF) each using D. desulfuricans and CAS bio-catalysts. For set 1 the reactor was charged with $250 \mathrm{mg}$ of commercial 5-HMF in $25 \mathrm{~mL}$ of MTHF ( $80 \mathrm{mM} \mathrm{5-HMF}$ solution); sets 2 and 3 used appropriate volumes of 5-HMF in MTHF extracted from starch and cellulose hydrolyzates, respectively, to the same final concentration of 5-HMF. In all sets a weight ratio of 5-HMF:catalyst of 2.5:1 was added to the reactor. The catalysts tested were commercial $\mathrm{Ru}-\mathrm{C}$ (5wt\% $\mathrm{Ru}$ on charcoal: Johnson Matthey), biorecovered $\mathrm{Ru}$ (bio-Ru; $5 \mathrm{wt} \%$ on CAS) and bimetallic preparations: $5 \mathrm{wt} \%$ $\mathrm{Pd} / 5 \mathrm{wt} \% \mathrm{Ru}$ bio- $\mathrm{Pd} / \mathrm{Ru}$ (nominally) on $D$. desulfuricans and CAS cells. The reactor was sealed, purged 3 times with $\mathrm{H}_{2}(50$ bar), pressurized with $\mathrm{H}_{2}\left(50\right.$ bar) and heated $\left(260^{\circ} \mathrm{C} ; 2 \mathrm{~h}\right.$; $500 \mathrm{rpm})$. After the reaction, the reactor was quenched to $35-$ $40^{\circ} \mathrm{C}$ in a water bath and the reaction mixture was filtered (Fisherbrand QL100 filter paper). Samples were stored at $-20^{\circ} \mathrm{C}$ before analysis.

\section{Analysis of Residual 5-HMF, 2,5 DMF and Co-products in the Catalytic Conversion Reaction}

Samples were analyzed using a GC-FID for quantification and a GCMS-QP2010s for compound identification. All GC-FID analysis was performed on a Shimadzu GC2014 equipped with a Shimadzu AOC-20i autosampler. The carrier gas was hydrogen, supplied by an external hydrogen generator (Parker). The GC was fitted with a Restek Stabilwax-DA column (30 m length, $0.32 \mathrm{~mm}$ ID, and $0.25 \mu \mathrm{m}$ film thickness). The injection volume was $1 \mu \mathrm{L}$ with a 39 split ratio. The inlet temperature was $250^{\circ} \mathrm{C}$. The detector was a flame ionization detector (FID) with a flame temperature of $300^{\circ} \mathrm{C}$, and a sampling rate of $40 \mathrm{~ms}$. The heating profile was $60^{\circ} \mathrm{C}$ for $2 \mathrm{~min}$ then heated to $200^{\circ} \mathrm{C}$ at $5^{\circ} \mathrm{C} / \mathrm{min}$ followed by further heating to $240^{\circ} \mathrm{C}$ at $15^{\circ} \mathrm{C} / \mathrm{min}$ where it remained for a further $3 \mathrm{~min}$. Analysis was carried out using Shimadzu GC solutions software. Calibration curves were third order between 80 and $0.4 \mathrm{mM}$.

All GC-MS analysis was performed on a Shimadzu GCMSQP2010s equipped with a Shimadzu AOC-20i autosampler. The carrier gas was helium. The GC was fitted with a Restek Rxi-1ms column (15 m length, $0.25 \mathrm{~mm} \mathrm{ID}$, and $0.25 \mu \mathrm{m}$ film thickness). The injection volume was $1 \mu \mathrm{L}$ with a -1 split ratio. The inlet temperature was $250^{\circ} \mathrm{C}$. The detector was a single quadrupole mass spectrometer in electron ionization mode. The detector and interface temperatures were $250^{\circ} \mathrm{C}$. The detector acquisition mode was scanning between 40 and $400 \mathrm{~m} / \mathrm{z}$, with a scan every $300 \mathrm{~ms}$. The solvent cut time was $1 \mathrm{~min}$. The heating profile was $60^{\circ} \mathrm{C}$ for $2 \mathrm{~min}$ then heated to $200^{\circ} \mathrm{C}$ at $5^{\circ} \mathrm{C} / \mathrm{min}$ followed by further heating to $240^{\circ} \mathrm{C}$ at $15^{\circ} \mathrm{C} / \mathrm{min}$ where it remained for a further $3 \mathrm{~min}$. Analysis was carried out using Shimadzu GCMS Real Time Analysis and Shimadzu GCMS Post Run Analysis 
software. 5-HMF conversions and 2,5 DMF yields were calculated as follows (Equations 2-5):

HMF conversion (\%. SM: starting material)

$$
\begin{gathered}
=1-\left(\frac{\text { moles of HMF in products }}{\text { Starting moles HMF }}\right) * 100 \\
\text { DMF yiels }(\%)=\frac{\text { moles of DMF in products }}{\text { Starting moles HMF }} * 100
\end{gathered}
$$

2, 5 DMF selectivity (\%)

$=\left(1-\frac{\text { moles of } 2,5-\mathrm{DMF} \text { in products }}{\text { starting moles of } 5-\mathrm{HMF}-\text { final moles of } 5-\mathrm{HMF}}\right)$ $\times 100$

$$
\begin{aligned}
& \text { DMF energy }\left(\frac{\mathrm{MJ}}{\mathrm{kg} \mathrm{SM}}\right) \\
& \quad=\left(\frac{\mathrm{kg} \text { of DMF in products }}{\mathrm{kg} \mathrm{SM}}\right) *\left(\frac{\mathrm{MJ}}{\mathrm{kg} \mathrm{DMF}}\right)
\end{aligned}
$$

\section{RESULTS AND DISCUSSION}

\section{Conversion of Starch and Cellulose to 5-HMF and HMF-MTHF Extraction}

The yields of 5-HMF from thermal hydrolysis of starch and cellulose were 130 and $40 \mathrm{mg}$ 5-HMF/g starting material (aq.), respectively. MTHF extraction efficiency of 5-HMF from the aqueous phase was between 59 and 63\% (from several preparations) resulting in 5-HMF concentrations in MTHF of 70 and $21 \mathrm{mM}$ for starch and cellulose, respectively, when pooled (Table 1). Example extraction efficiencies from two independent preparations were 59.3 and $62.8 \%$, however, the actual efficiency is of relatively low importance for proof of principle since this specific method would require further development for scale up and final application. For example a cost-benefit analysis would consider a raft of solvents for efficiency and economy at scale although the potential benefirts of MTHF are already apparent (see Introduction).

The yield of 5-HMF obtained from starch hydrolysis was consistent with previous work (Miyazawa, 2005; Orozco, 2012) but the yield from cellulose was markedly lower (Table 1). This could be expected as the crystalline structure of cellulose makes it more difficult to hydrolyze, requiring higher temperatures, however, this also enhances reaction degradation pathways of 5HMF to simpler structures such as formic and levulinic acids

TABLE 1 | Conversion of starch and cellulose to 5-HMF and extraction efficiency of MTFH.

\begin{tabular}{lcc}
\hline & Starch & Cellulose \\
\hline Conversion to 5-HMF (mg 5-HMF/g SM*) & 130 & 40 \\
MTHF extraction efficiency of 5-HMF (\%) & 59.6 & 62.8 \\
[5-HMF] in MTHF (supernatant; mM) & 70 & 21 \\
\hline
\end{tabular}

*SM = starting material (starch or cellulose).
(Minowa et al., 1998; Palmqvist and Hahn-Hägerdal, 2000). This additional complexity was confirmed by examination of example product mixtures by GC (Supplementary Figure S1A) but the actual amounts of products (other than DMF) were not determined.

The yield from cellulose was $\sim 2.5$ times lower than values reported from hot compressed water hydrolysis of cellulose (e.g., $\sim 110 \mathrm{mg}$ 5-HMF/g cellulose @ 260 ${ }^{\circ} \mathrm{C}$ ) (Minowa et al., 1998; Kamio et al., 2006; Orozco, 2012). Minowa et al. (1998) studied the decomposition of cellulose in hot compressed water with alkali or nickel catalysts; the positive effect of these on the cellulose degradation pathway to products was significant as compared to catalyst-unsupplemented conditions. The reactor vessel used by Kamio et al. (2006) and Orozco (2012) was made of Hastelloy C-22 and C-276, respectively, both containing a nickel $(\sim 55 \%)$-molybdenum-chromium alloy. Unpublished work (Orozco, 2012) attributed an improvement in cellulose conversion to possible leaching of catalytic metals from the reactor body. These materials, when corroded, are known to leach metals to the reaction medium thereby possibly affecting cellulose decomposition and product distribution (Yu et al., 1993; Lu et al., 2006). Possible benefits of catalyst-enhanced hydrolysis may be suggested, however, the presence of heavy metals in the hydrolyzate is likely to inhibit its downstream fermentation due to metal toxicity. The use of added catalyst (and its removal from the product mixture) was beyond the scope of this study although immobilized biofilm-catalyst has been used in other applications, e.g., of removal of toxic $\mathrm{Cr}(\mathrm{VI})$ via bioPd-mediated reduction (Yong et al., 2015). The reactor used in the present work comprised stainless steel 316 containing $\mathrm{Fe}$ ( $65 \%)$, $\mathrm{Ni}(\sim 12 \%)$, and $\mathrm{Cr}(17 \%)$ alloy; metal leaching was not determined but successful biohydrogen fermentations of the hydrolyzate were reported following removal of toxic 5-HMF (Orozco, 2012). The lower yields of 5-HMF and the presence of more degradation products in the cellulose hydrolysate (Supplementary Figure S1A) would have an adverse effect on the delivery of additional energy. Ideally the continuous extraction of 5 -HMF during the biomass hydrolysis reaction would be desirable to avoid further degradation of this compound which occurs at high temperatures (Saha and Abu-Omar, 2014), e.g., by addition of a solvent extraction loop with organic phase removal. This would be particularly important for 5-HMF derived from hydrolysis of cellulose, which typically requires a higher reaction temperature.

The MTHF extraction efficiency of 5-HMF from the aqueous phase was comparable, at $\sim 60$ and $63 \%$ from starch and cellulose hydrolyzates, respectively, delivering organic supernatants containing 8.8 and $2.2 \mathrm{~g} / \mathrm{l}$ (70 and $21 \mathrm{mM}$ ) of 5HMF (Table 1). The initial concentrations of 5-HMF in the aqueous phase and the effect of sugars present in the hydrolyzate will have an influence on the partition coefficient of 5-HMF which can be significantly higher with increasing concentrations. For example, the presence of $30 \% \mathrm{wt} / \mathrm{vol}$ fructose in MTHF increased the partition coefficient of 5-HMF from 2.1 up to $36 \%$ (Blumenthal et al., 2016). The goal is separation and catalytic upgrading to DMF in the same solvent, hence the 5-HMF partition coefficient must be maximized while minimizing the 


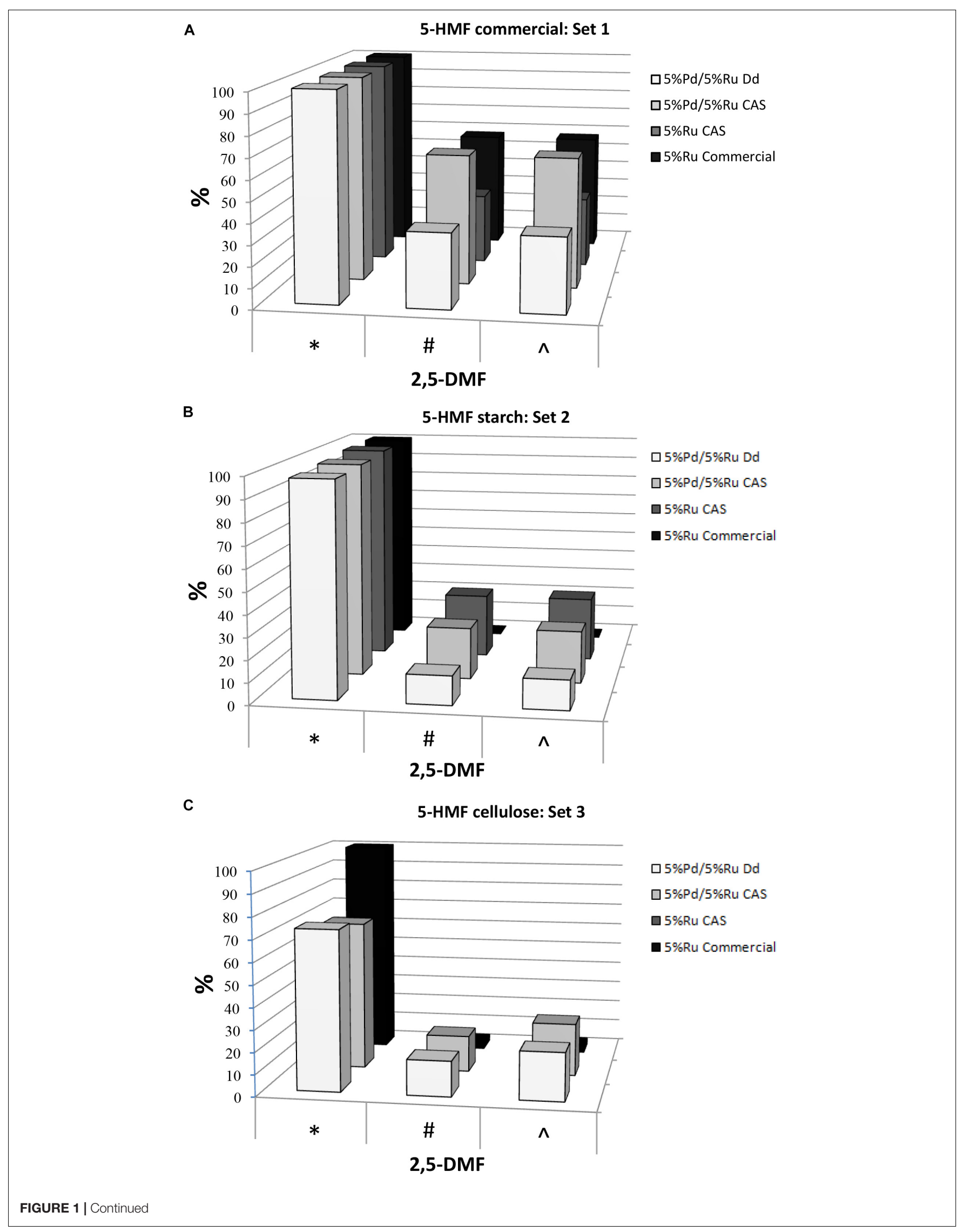


FIGURE 1 | Conversion of 5-HMF from commercial source (A) and from starch (B) and cellulose (C) hydrolyzates by commercial 5\%Ru on carbon catalyst, 5 wt $\%$ bio-Ru on sulfidogenic waste culture (CAS), 5wt\%Pd/3wt\%Ru on D. desulfuricans (nominal loading was 5wt\% Pd/5wt\% Ru: see later) and 5wt\%Pd/5wt\%Ru on CAS as shown. Experiments were done at least twice on separate occasions and data are shown in Supplementary Table S1B. X axis: *Conversion of 5-HMF (\%) \#Yield of 2,5-DMF (\%). ^ Selectivity to 2,5-DMF (\%).

glucose partition coefficient. These studies were beyond the scope of this investigation, however, a lack of solubility of glucose in MTHF suggests it would be unlikely that glucose was removed from the hydrolyzate during the 5-HMF extraction process.

Other approaches for 5-HMF removal such as over-liming, activated carbon, zeolites and ion exchange resins selectively removed up to $85 \%$ of 5-HMF (Ezeji et al., 2007; Hodge et al., 2009; Jin et al., 2015; Ma et al., 2017). However, the recovery of 5 -HMF from these extraction substrates is either difficult or unfavorable for downstream processing into 2,5-DMF due to high intramolecular attraction between 5-HMF and the extraction substrates or the regenerant/eluting agents containing water or water miscible organic solvents (Liu et al., 2015).

The efficiency of MTFH in the hydrogenation reactions compared to THF was evaluated in a set of reactions as shown in Supplementary Table S1A. In all cases MTHF proved to be a better solvent than THF, delivering higher conversion and yields of DMF. It is concluded that MTHF is able to both extract 5-HMF from the hydrolyzate and serve as the solvent for its upgrading, facilitating a one-stage reaction.

\section{Hydrogenation of 5-HMF Into 2,5 DMF Using Ru and Pd Catalysts}

The Pd was removed onto the bacteria in the first step to give 5 wt $\%$ loading of Pd. In the second step all of the Ru(III) was removed by the CAS cells (loading was $5 \mathrm{wt} \% \mathrm{Pd} / 5 \mathrm{wt} \% \mathrm{Ru}$ ) whereas the D. desulfuricans only loaded Ru (III) to $3 \mathrm{wt} \%$ (actual catalyst composition was $5 \% \mathrm{Pd} / 3 \% \mathrm{Ru}$ ). The reason for this was not investigated further (see later Discussion).

The hydrogenation tests for the three 5-HMF substrates are summarized in Figure $\mathbf{1}$ (with the data and errors shown in Supplementary Table S1B) For set 1 (pure 5-HMF) and set 2 (5-HMF from starch) the conversion of 5-HMF to products was generally between 95 and 100\% (Figure 1). In contrast using 5-HMF from cellulose (set 3) the conversion was between 61 and $81 \%$ reaching $100 \%$ only with $5 \% \mathrm{Ru}$ commercial catalyst but delivering a very poor yield of DMF (3\%: Figure 1C). It is concluded that, while commercial $\mathrm{Ru}$ catalyst is useful for DMF production from pure 5-HMF, it is virtually ineffective in producing DMF from the hydrolyzates (Figures 1B,C). The reason for this was not investigated but may be due to fouling of the commercial catalyst by reaction components or products or to over-reaction yielding other products which were neither identified nor quantified. Example chromatograms showing reaction products are shown in Supplementary Figure S1B. Notably, both types of bio-Pd/Ru gave significant DMF product from the hydrolyzates where the commercial counterpart was ineffective (Figures 1A-C and Supplementary Table S1B). In addition, using cellulose hydrolyzate, both types of bio$\mathrm{Pd} / \mathrm{Ru}$ bimetallic performed comparably (Figure 1C) whereas the DMF yield and selectivity in starch hydrolyzate using CAS was $\sim$ double that yielded via catalyst made using bio-Pd/Ru on D. desulfuricans (Figure 1B). This difference was not attributable to an effect of any component of the hydrolyzate since the effect was clear also with pure 5-HMF substrate (Figure 1A).

The highest yields of DMF obtained corresponded to $5 \% \mathrm{Pd} / 5 \% \mathrm{Ru}$ on CAS using commercial 5-HMF $(63.13 \%)$ and $5 \% \mathrm{Ru}$ on CAS cells using 5-HMF from starch $(29.3 \%)$ this being 46\% lower; in both cases almost 100\% 5-HMF conversion was achieved. This difference using the starch hydrolyzate could be attributed to the occurrence of side reactions caused by the presence of other by products in the starch derived 5HMF (see GC chromatograms; Supplementary Figure S1B). The commercial Ru-catalyst gave $57 \%$ yield of DMF using pure 5 -HMF (set 1) but when reacted on starch-derived 5-HMF (set 2) the yield was negligible which has negative implications for the application of the commercial catalyst in biomass product upgrading.

In terms of potential energy to be gained from the produced DMF: set 2 (5\% Pd/5\%Ru CAS) would give $2.1 \mathrm{kWh} / \mathrm{kg}$ starchderived 5-HMF and set $1(5 \% \mathrm{Pd} / 5 \% \mathrm{Ru}$ CAS $) 4.6 \mathrm{kWh} / \mathrm{kg}$ commercial 5-HMF. These energy yields would contribute to mitigate by $\sim 28$ and 63\%, respectively, of the "parasitic" energy needed for the hydrolysis and catalytic reactions $(7.3 \mathrm{kWh} / \mathrm{kg}$ 5 -HMF) assuming $80 \%$ heat recovery from the reactions. The equivalent potential energy gains using the bimetallic catalyst made on $D$. desulfuricans would be $0.95 \mathrm{kWh} / \mathrm{kg}$ from starchderived 5-HMF. The $>2$-fold better performance of the catalyst made on the CAS as compared to $D$. desulfuricans prompted comparison of metal deposition by the two sulfidogenic cultures. As noted above, the $D$. desulfuricans loaded $60 \%$ of the Ru(III) and hence the approximate proportions of metals (Ru:Pd) were $0.6: 1$ and $1: 1$, respectively, for the $D$. desulfuricans and CAS materials; other possible differences between them were sought.

\section{Formation of Bimetallic Material by Washed Cells of the Sulfidogenic Cultures}

\section{Bio-Pd/Ru Supported on $D$. desulfuricans}

Palladium (II) was completely removed from the challenge solution by both sets of cells (estimated as in Omajali et al., 2015) and uptake into/into the cells to $5 \mathrm{wt} \% \mathrm{Pd}$ was concluded. Formation of $\operatorname{Pd}(0)$ on $D$. desulfuricans was described previously (Omajali et al., 2015). Here, at a loading of $20 \mathrm{wt} \% \mathrm{Pd}$ both cell surface-localized and intracellular Pd-nanoparticles were observed (Supplementary Figure S2). The occurrence of metal intracellularly implies an uptake mechanism but its relatively low occurrence in the cytoplasm could imply an effective efflux mechanism as a detoxification response which is a well known metal resistance mechanism and a way to ensure that cells retain essential metals while rejecting toxic ones 
(Waldron and Robinson, 2009). At a loading of $5 \mathrm{wt} \%$ Pd (i.e., for the Pd pre-loading as used in this study) little intracellular $\operatorname{Pd}(0)$ was observed (Supplementary Figure S3 and inset). This is in contrast to (non-sulfidogenic) E. coli where Pd-NPs were visible throughout the cells (Supplementary Figure S3 and inset). While Pd deposition in E. coli did not co-map with either phosphorus or sulfur the elemental maps (Supplementary Figure S3) indicated
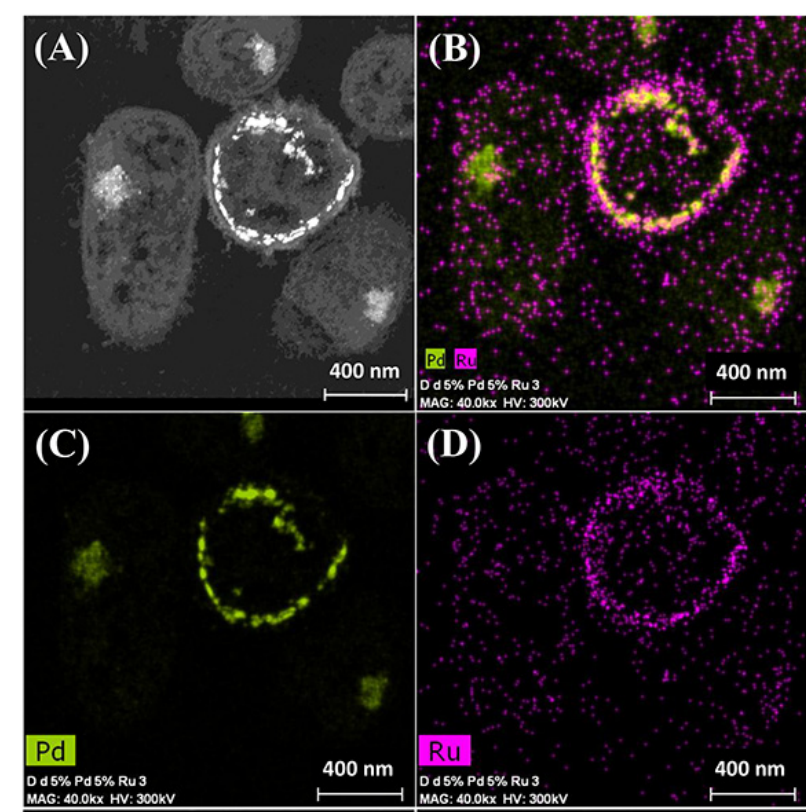

(D)
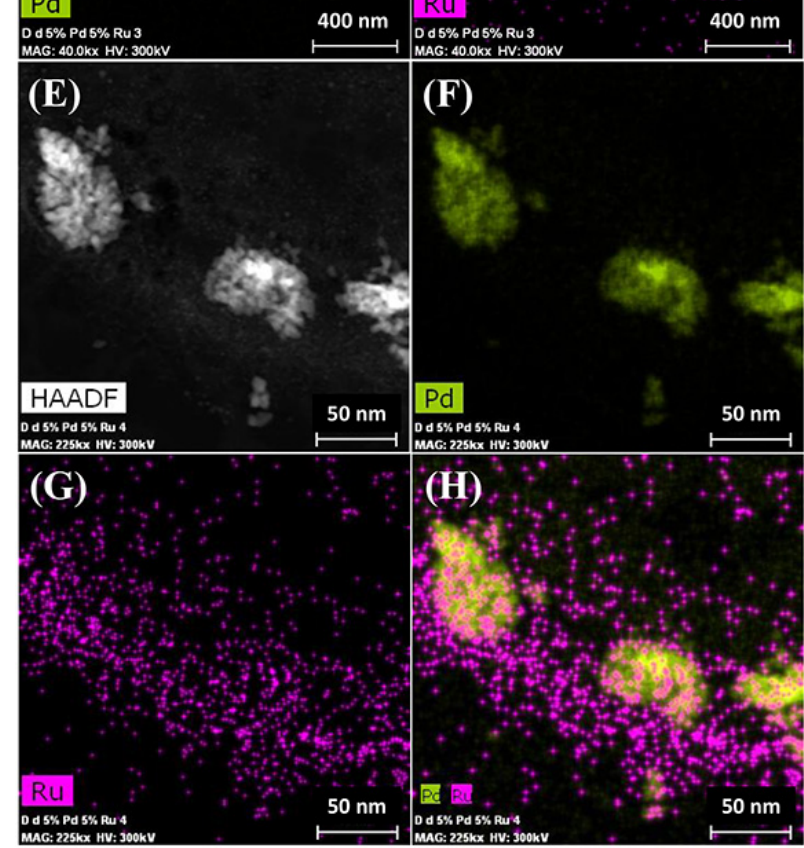

FIGURE 2 | Deposition of 5wt\% Pd/3wt\% Ru by Desulfovibrio desulfuricans and co-localization of the metals on the cells. Arrows: dense nuclear bodies typical of slowly-growing cells. (A) HAADF image where metallic NPs appear bright. (B) elemental map of $\mathrm{Pd}$ (green) and Ru (magenta); individual elementa maps are shown in (C,D). (E) HAADF image of discrete NPs in the cell surface region mapped for $\mathrm{Pd}(\mathbf{F}$, green) and $\mathrm{Ru}(\mathbf{G}$, magenta) and co-localization of $\mathrm{Pd}$ and $\mathrm{Ru} \mathbf{( H )}$.
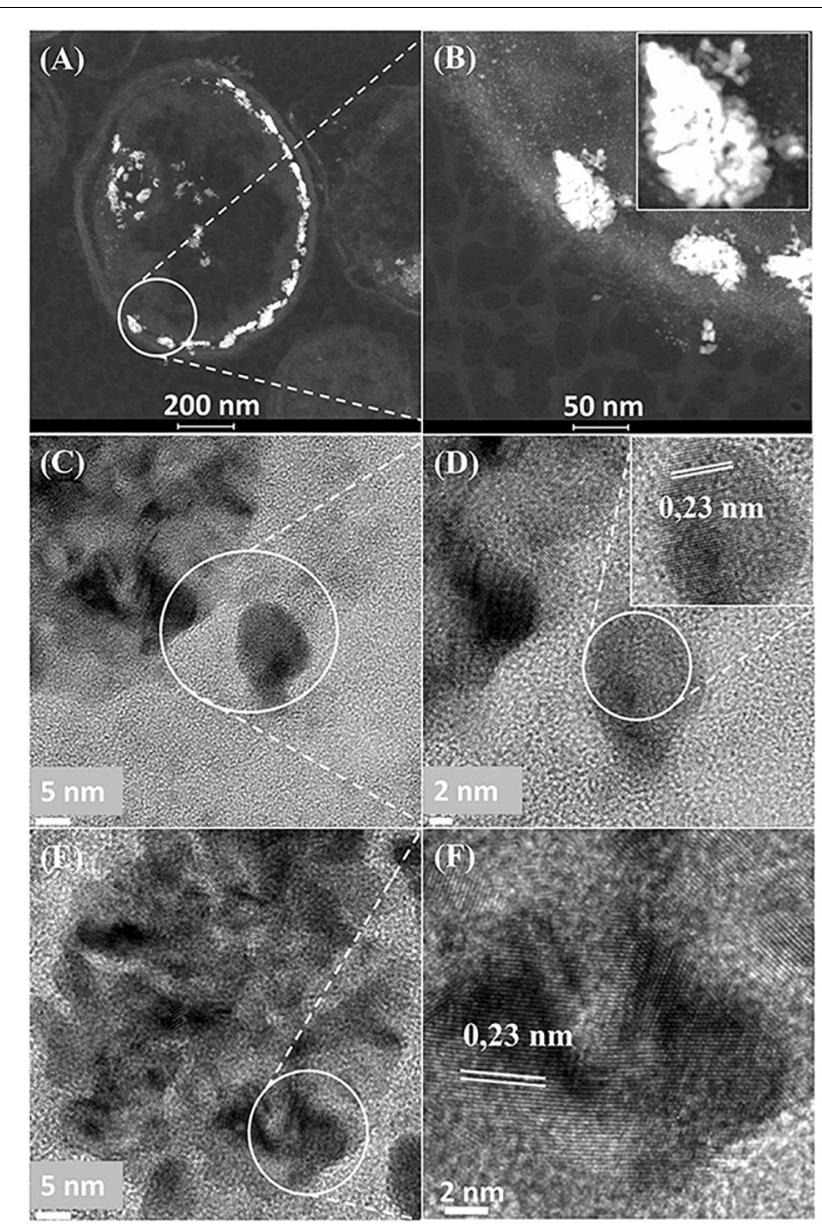

FIGURE 3 | (A) Region of cell surface shown in Figures 2E-H. Enlarged image (B, inset) shows that the large NPs are agglomerations of smaller ones. Crystal lattice spacings are shown for a NP outside (C,D) and within (E,F) an agglomeration.

TABLE 2 | The sulfidogenic waste culture used in the study compared to D. desulfuricans.

\begin{tabular}{lccc}
\hline Bacterium & \% representation & Gram stain & Sporeformer \\
\hline $\begin{array}{l}\text { D. desulfuricans } \\
\text { CAS: Desulfosporosinus }\end{array}$ & 100 & Gram negative & - \\
$\begin{array}{l}\text { acididurans* } \\
\text { CAS: Unidentified strain }\end{array}$ & 66 & Gram positive & + \\
CEB & 7 & NK & NK \\
CAS: Acidocella aromatica & 10 & Gram negative & - \\
CAS: Actinobacterium & 10 & Gram positive & + \\
CAS: Acidithiobacillus & 7 & Gram negative & -
\end{tabular}

ferroroxidans

NK, not known. Only $17 \%$ of the CAS population were the same cell type as $D$. desulfuricans (Gram negative, non-sporeformer). The majority were Gram positive sporeformers (76\%).

a co-deposition of Pd with S, at least in part, in the cell surface layers of washed cells of $D$. desulfuricans. This is in accordance with earlier data from X-ray photoelectron spectroscopy that indicated formation of Pd-S bonds (and hence some palladium 

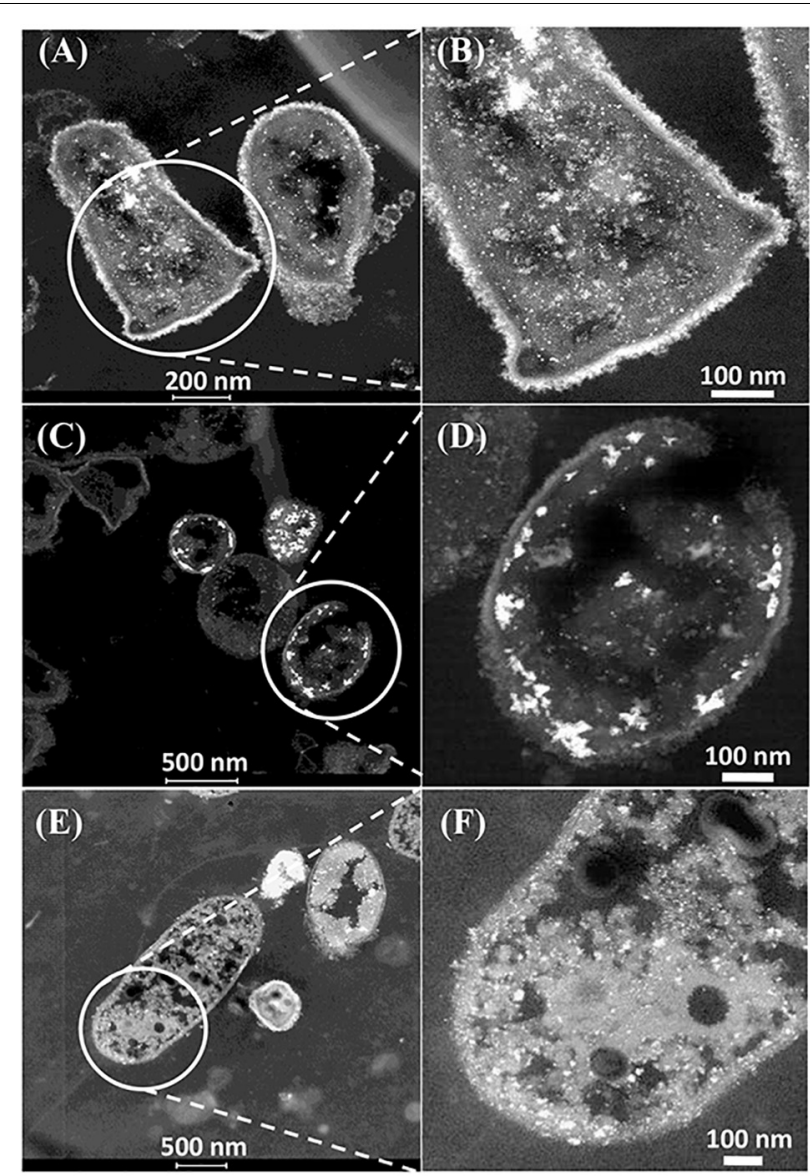

FIGURE 4 | Examination of the CAS bacteria loaded with $5 w t \% R u / 5 w t \% P d$. Three main patterns of metal deposition are attributed to type I (A,B), type ॥ (C,D), and type III (E,F) cells.

sulfide species) in the cell surface (outermost $\sim 10-30 \mathrm{~nm}$ ) layers of $D$. desulfuricans (Omajali, 2015). It is not known if the putative palladium sulfide was formed from incoming or effluxing $\mathrm{Pd}(\mathrm{II})$.

Previous studies (Omajali et al., 2015; Williams, 2015) identified three populations of palladium nanoparticles (NPs) in D. desulfuricans: NPs in the cell surface layers, in the cytoplasm and localized within nuclear bodies (NBs: the intracellular inclusion nuclear body is shown in Supplementary Figure S2). NBs are a condensed form of DNA that commonly occurs in

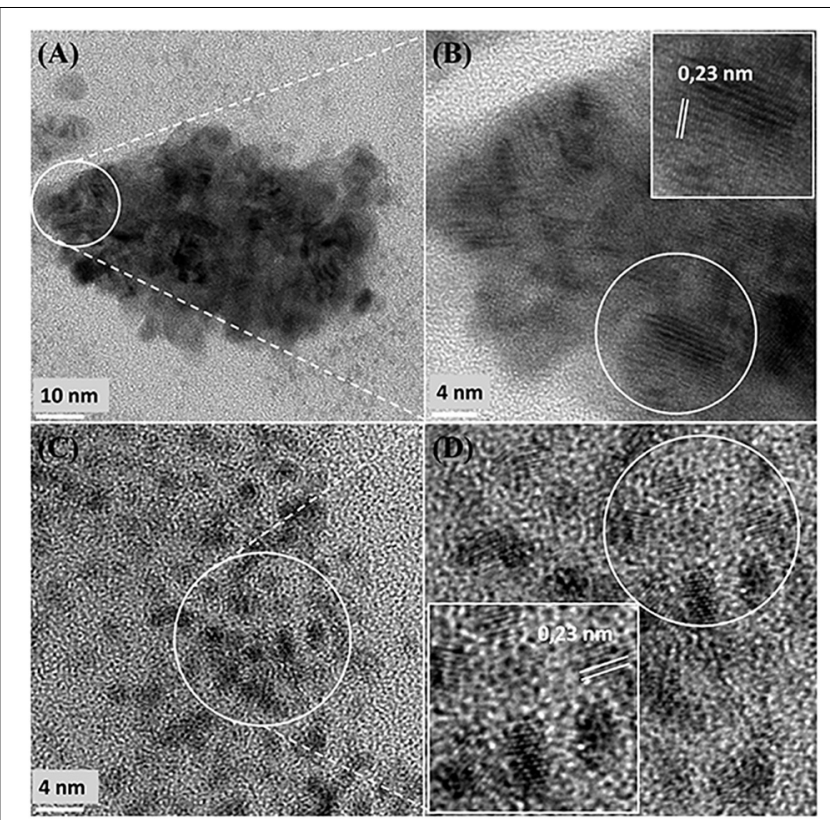

FIGURE 5 | High resolution-TEM analysis of cell sections showing cluster $(\mathbf{A}, \mathbf{B})$ taken from Figure 4B (Panel B) and $\mathbf{( C , D )}$ taken from Figure 4B (Panel D) shows lattice spacing of $0.23 \mathrm{~nm}$.

cultures in stationary phase or when grown at a slow growth rate (Zaritsky et al., 2017). Pd is well known to bind to DNA (Pillai and Nandi, 1977) and/or histone-like, DNA-associated proteins. Actively growing cells produce $\mathrm{H}_{2} \mathrm{~S}$, and a growing culture comprises a mixture of "young" (freshly divided) and "old" cells as well as dead cells. Hence, the D. desulfuricans culture would comprise a population of cells each at different stages of their cell cycle, with actively metabolizing and also senescent cells, from which $\mathrm{H}_{2} \mathrm{~S}$ would possibly not be produced from residual metabolism. The possibility that incoming $\mathrm{Ru}(\mathrm{III})$ faces a potential "choice" between $\operatorname{Pd}(0), \operatorname{PdS}$ (or other localization foci other than Pd-"seeds") has not been considered previously as sulfidogenic cultures have not been examined in detail (Omajali, 2015; Supplementary Figure S3).

It was assumed that $5 \mathrm{wt} \% \mathrm{Pd}(0)$ NPs serve as the putative "seeds." for Ru deposition, on the basis of earlier work on the formation of Pd/Au bimetallic catalysts (Deplanche et al., 2012). However, unlike with $\mathrm{Au}(\mathrm{III})$ reported previously using E. coli (Deplanche et al., 2012), the Ru(III) was incompletely removed

TABLE 3 | Atomic percentages of outermost $\sim 10 \mathrm{~nm}$ of metallized bacterial cells determined by XPS.

\begin{tabular}{|c|c|c|c|c|c|c|c|c|c|}
\hline Sample & Ru & Pd & C & 0 & $\mathbf{N}$ & $\mathbf{S}$ & Cl & $\mathbf{P}$ & $\mathrm{Ca}$ \\
\hline E. coli $5 \% \mathrm{Pd} / 4.7 \% \mathrm{Ru}^{*}$ & 2.42 & 0.14 & 71.48 & 19.81 & 4.30 & 0 & 0 & 0.80 & 0 \\
\hline D. desulfuricans $5 \% \mathrm{Pd} / 3 \% \mathrm{Ru}$ & 1.03 & 0.12 & 68.88 & 21.44 & 5.18 & 0.38 & 0.17 & 0.38 & 0.21 \\
\hline CAS 5\% Ru & 1.40 & 0 & 64.37 & 21.95 & 7.08 & 1.18 & 0 & 0.41 & 0 \\
\hline CAS 5\%Pd/5\%Ru & 5.30 & 0.41 & 64.36 & 18.78 & 6.01 & 3.55 & 0.11 & 1.39 & 0 \\
\hline
\end{tabular}

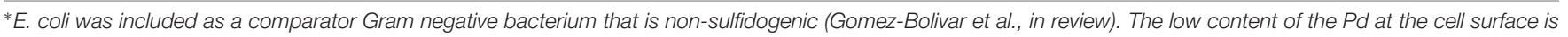
attributable to internalization into the lower cellular layers beyond the detection of XPS. 
by $D$. desulfuricans (see above) and the metal loading onto the cells was $5 \mathrm{wt} \% \mathrm{Pd} / 3 \mathrm{wt} \% \mathrm{Ru}$. Figure $2 \mathrm{~A}$ shows the formation of metallic NPs in the nuclear bodies of $D$. desulfuricans (Figures 2A,C) and also localized at the cell surface. The deposition of $\mathrm{Ru}$ in the cells was greater than the background, but there was no clear association with Pd or any cellular feature in cells showing nuclear bodies (Figures 2B,D) whereas a colocalization of $\mathrm{Pd}$ and $\mathrm{Ru}$ was evident in cell surface layers (Figure 2B and Supplementary Figure S4). Putative bimetallic structures occurred at the cell surface, in addition to localizations where an association between $\mathrm{Pd}$ and $\mathrm{Ru}$ (with apparent $\mathrm{Ru}$ outgrowths) was suggested (Supplementary Figure S4). In contrast, in another example cell, discrete Pd-NPs in the surface layers showed no clear association of $\mathrm{Pd}$ and $\mathrm{Ru}$ and deposition of the latter appeared to be uniform throughout the cell surface (Figures $2 \mathbf{E}-\mathbf{H}$ ). The distribution of $\mathrm{Ru}$ appeared to be independent of the Pd-NPs (Supplementary Figure S4) and it is not known whether the apparent $\mathrm{Ru}$ "overgrowths" were coincidental or in association with Pd nucleation. Examination of examples of cell surface regions showed (Figures 3A,CF) the large NPs to comprise agglomerations of smaller ones of sizes $\sim 5-7 \mathrm{~nm}$ (Figure 3B, inset) with lattice fringes of $0.23 \mathrm{~nm}$. This could correspond to the (110) plane of $\mathrm{RuO}_{2}$ (Soin et al., 2012) but the (111) plane of $\operatorname{Pd}(0)$ was noted by Divakar and Raghunathan (2003) as $0.24 \pm 0.01 \mathrm{~nm}$ and so the bio-NPs could equally be reporting the (111) facets of $\mathrm{Pd}(0) \cdot \operatorname{Pd}(0)-\mathrm{NPs}$ on $D$. desulfuricans were reported with $\mathrm{Pd}$ (111) lattice spacings of $0.250,0.258$, and $0.243 \mathrm{~nm}$ (Omajali et al., 2015). However, recent work in a purely chemical system has noted lattice spacings of palladium sulfide as 0.250 and $0.256 \mathrm{~nm}$, attributed to the expansion of the $\operatorname{Pd}(0)$ lattice by sulfur (Albani et al., 2018). Hence, the identity of the bio-nano crystals we report here cannot be attributed with certainty (see later Discussion).
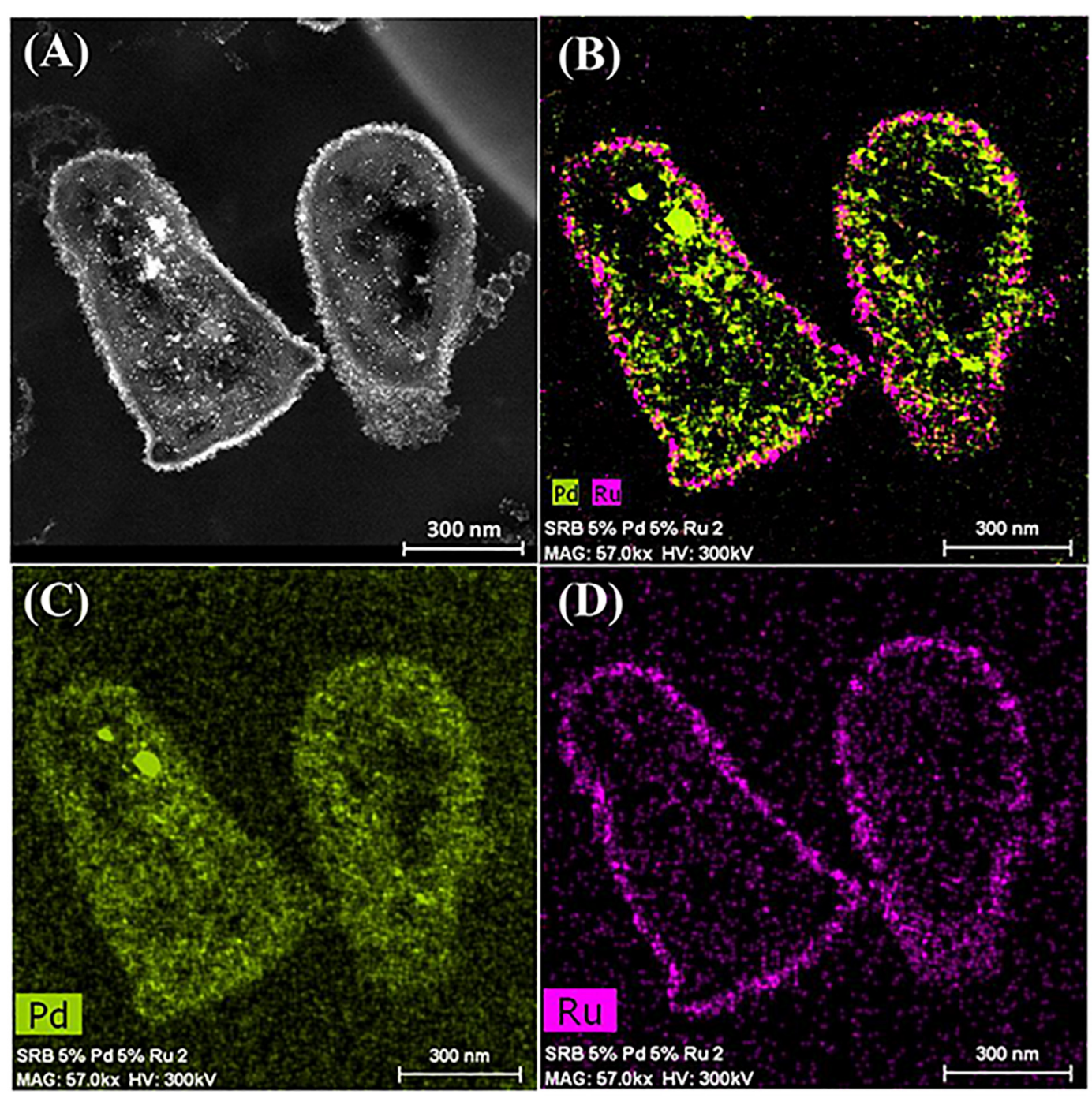

FIGURE 6 | Elemental mapping of distribution of Ru and Pd in two type I cells (as in Figure 4) showing superimposition of Pd (green, B) and Ru (magenta, D) occurrences. Individual maps (C,D) show very little Ru inside the cells although Pd is distributed uniformly between the cell surface and intracellular regions. 


\section{Waste Culture of Consortium of Acidophilic Sulfidogens (CAS)}

$D$. desulfuricans is a Gram negative anaerobic SRB that respires at the expense of sulfate in lieu of oxygen. The final product is $\mathrm{H}_{2} \mathrm{~S}$. Early work to remediate acid mine drainage waters (AMD) developed the use of acidophilic (acid-tolerant) sulfate-reducing bacteria (see Introduction) to precipitate heavy metals as their sulfides. Later work developed a mixed sulfate-reducing bacterial consortium into a continuous process whereby the $\mathrm{H}_{2} \mathrm{~S}$ off-gas precipitated metal sulfides, leaving the bacterial cells as the waste for use in this study. Samples were taken from the culture (in two periods separated by several weeks) that had been operating in a continuous mode for $>5$ years.

Examination of the CAS culture using SEM showed a variety of cell types (Supplementary Figure S5A), mostly comprising rod-shaped cells, some round structures and some small round bodies (presumably spores) both free and budding from some of the cells. Examination of the cell surfaces (bulk population) by XPS (see later) showed no calcium; calcium dipicolinate (CDP) is a major component of the bacterial spore and hence it may be concluded that the occurrence of bacterial spores in the mixture was below the limit of detection. However, the CDP resides below the outermost spore coat, being released upon germination (De Vries, 2004) and, since the penetration depth of XPS is in the order of $10-30 \mathrm{~nm}$, this is not a definitive conclusion but may tend to confirm the low occurrence of spore-type small round structures visible by SEM (Supplementary Figure S5A).

Analysis of the CAS cell population using molecular biology identification methods revealed its composition as $66 \%$ Desulfosporosinus acididurans (sp. nova: Sánchez-Andrea et al., 2015) $7 \%$ unidentified strain CEB, $10 \%$ Acidocella aromatica strain PFBC, 10\% Actinobacterium AR3 and 7\% Acidithiobacillus ferrooxodans (Santos and Johnson, unpublished; Table 2) Hence, although the $D$. desulfuricans and $17 \%$ of the mixed culture would be united by their Gram-negative stain and nonsporeforming characteristic, $76 \%$ of the CAS would comprise Gram positive sporeformers.

The Gram-negative bacterial cell surface comprises a phospholipid outer membrane (OM) containing lipopolysaccharide that often bridges into extracellular hydrated polymeric materials which collapse upon drying. Beneath the $\mathrm{OM}$ the periplasmic space comprises a hydrated gelcompartment of width $\sim 30 \mathrm{~nm}$ and beneath that the inner membrane (IM), which is the cellular permeability barrier bounding the cytoplasm. The periplasmic space contains structural peptidoglycan, the $\mathrm{N}$-acetyl glucosamine components of which would provide amine groups for potential coordination of incoming metals. The classical Gram positive cell lacks the $\mathrm{OM}$ and periplasmic space and its single membrane is bounded externally by a thick layer of peptidoglycan (as in the Gramnegative periplasmic space), which also contains phosphate in the form of teichoic acids embedded within it. In addition, there is often a coat of regular protein structures, the "S-layer" (which can also be found on Gram-negative cells) which is present in many Gram positive bacteria including Bacillus sphaericus strains isolated from heavy metal-contaminated sites
(Merroun et al., 2005). This outermost surface layer plays a major role in the coordination of heavy metals and radionuclides through its carboxyl and phosphate groups (Merroun et al., 2005). In addition, archaea and Gram positive bacterial S-layer has been used as a template for the fabrication of metallic NPs of Au (Merroun et al., 2007; Bartolome et al., 2012). Bacterial cell surfaces have been extensively reviewed per se and in the context of metal binding behavior (e.g., Beveridge, 1989). It is
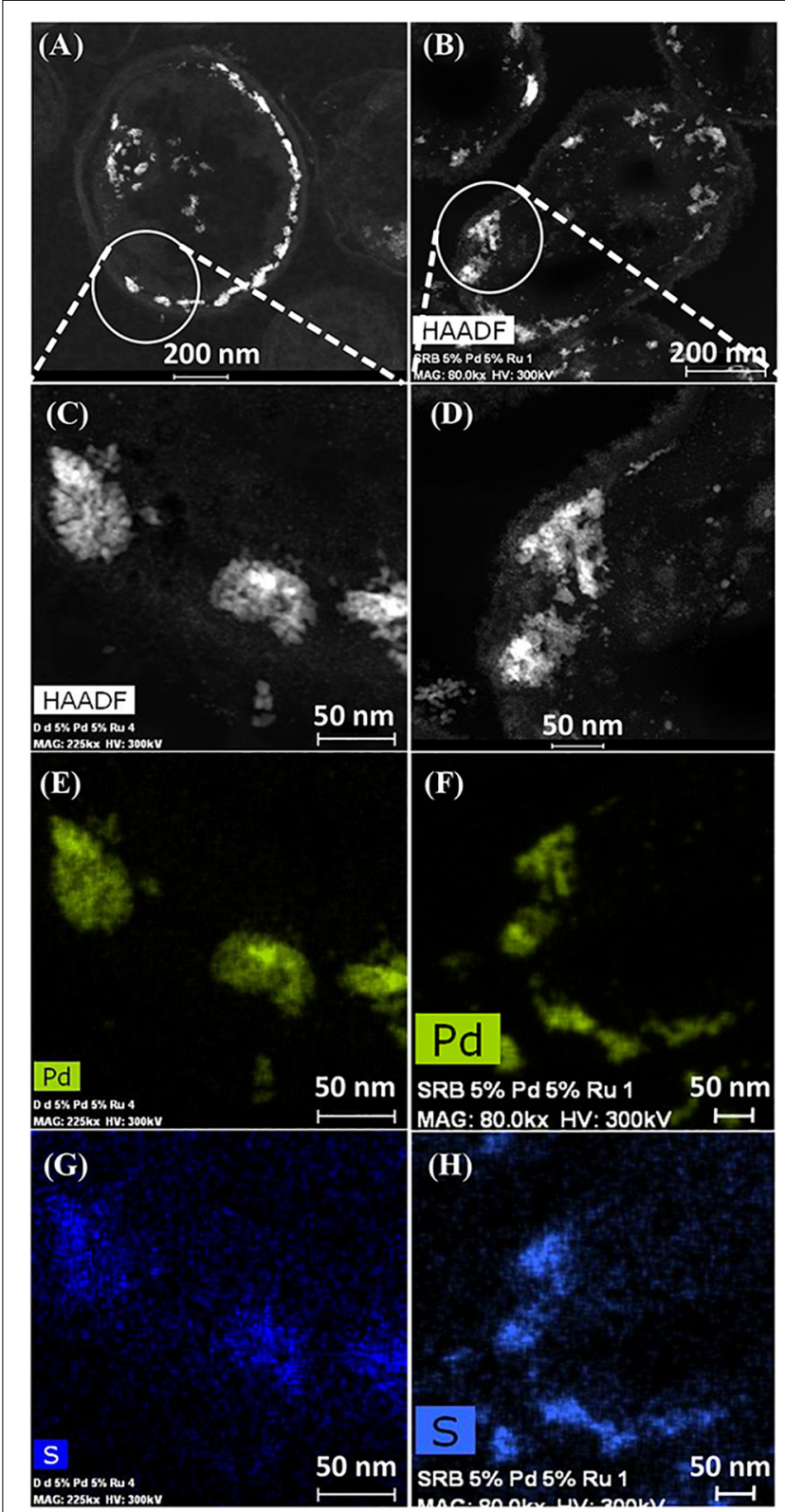

FIGURE 7 | HAADF/STEM images of $D$. desulfuricans (A) loaded with 5 wt $\%$ $\mathrm{Pd} / 3 w t \% \mathrm{Ru}$ and CAS cells type II loaded with $5 \% \mathrm{Pd} / 5 \% \mathrm{Ru}$ (B). Magnifications show similar clusters on sulfidogenic bacteria (D) and D. desulfuricans (C) located in the periplasm. Qualitative analysis using EDX elemental mapping shows superimposition in CAS bacteria for $\mathrm{Pd}(\mathbf{F})$ and

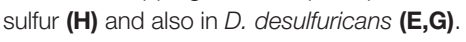


assumed that binding of $\mathrm{Ru}(\mathrm{III})$ to Gram positive cells accesses more, or different, nucleation sites than onto Gram negative cells (e.g., via the higher content of surface-accessible petidoglycan in the former) but this was not tested.

\section{Formation of Metallic Nanoparticles on CAS}

The CAS was metallized with $5 \mathrm{wt} \% \mathrm{Pd} / 5 \mathrm{wt} \% \mathrm{Ru}$ and examined in the light of the above discussions (Figure 4). Electron micrographs of the metallized CAS are also shown in Supplementary Figures S5B,C, S6. The cell heterogeneity is apparent in Supplementary Figure S5 and expansion of cell surface areas (Figure 4 and Supplementary Figure S6) shows four types on the basis of their pattern of metal deposition (c.f. Table 3) but each type could not be attributed to a taxonomic group on the basis of morphology alone. Type I cells (Figures $\mathbf{4 A}, \mathbf{B}$ ) showed heavy metallic deposits at the outer edge of the cell surface in addition to intracellular nanoparticles. Type II (Figures 4C,D) showed no outermost metal deposits, but instead dense metallic deposits co-localized beneath the wall layers and some intracellular NPs. Type III (Figures 4E,F) showed metallic NPs within the wall layers and also intracellularly. Figure $4 \mathrm{E}$ also shows a putative spore (type IV) but as the small round structures were numerically sparse (Supplementary Figure S5A) these were not considered to play a major role, although metallic deposits were apparent on the surface and within the putative spores (Supplementary Figure S6G). Some cells showed outer membrane vesicles (Figure 4A and Supplementary Figure S6H), too few in number to contribute to the overall metal deposition.

Further examination of the metallic NPs is shown in Supplementary Figure S6. Note that in type I cells (Supplementary Figures S6A,B) the NPs are generally separated, located on the outer face of the cell wall and of dimensions $\sim$ $2 \mathrm{~nm}$ whereas in type II cells (Supplementary Figures S6C,D) the NPs are larger (e.g., >50 nm) and appear as agglomerations. Type III cells (Supplementary Figures S6E,F) appear to have a layered cell surface structure (Supplementary Figure S6F) typical of a Gram negative cell but this was not confirmed. As with $D$. desulfuricans (above) the lattice fringes were $0.23 \mathrm{~nm}$ (Figure 5), i.e., the nanocrystals could have been either $\operatorname{Pd}(0)$ or $\mathrm{RuO}_{2}$ or, indeed, a form of palladium sulfide (see above). Much of the NP material appeared to be amorphous or non-crystalline as evidenced by a lack of lattice fringes.

Elemental mapping by energy dispersive X-ray microanalysis (Figure 6) showed that, in type I cells, while Pd was dispersed throughout the cell surface and cytoplasmic layers, the $\mathrm{Ru}$ deposits were almost exclusively confined to the cell surface with occasional intracellular occurrences scarcely higher than the
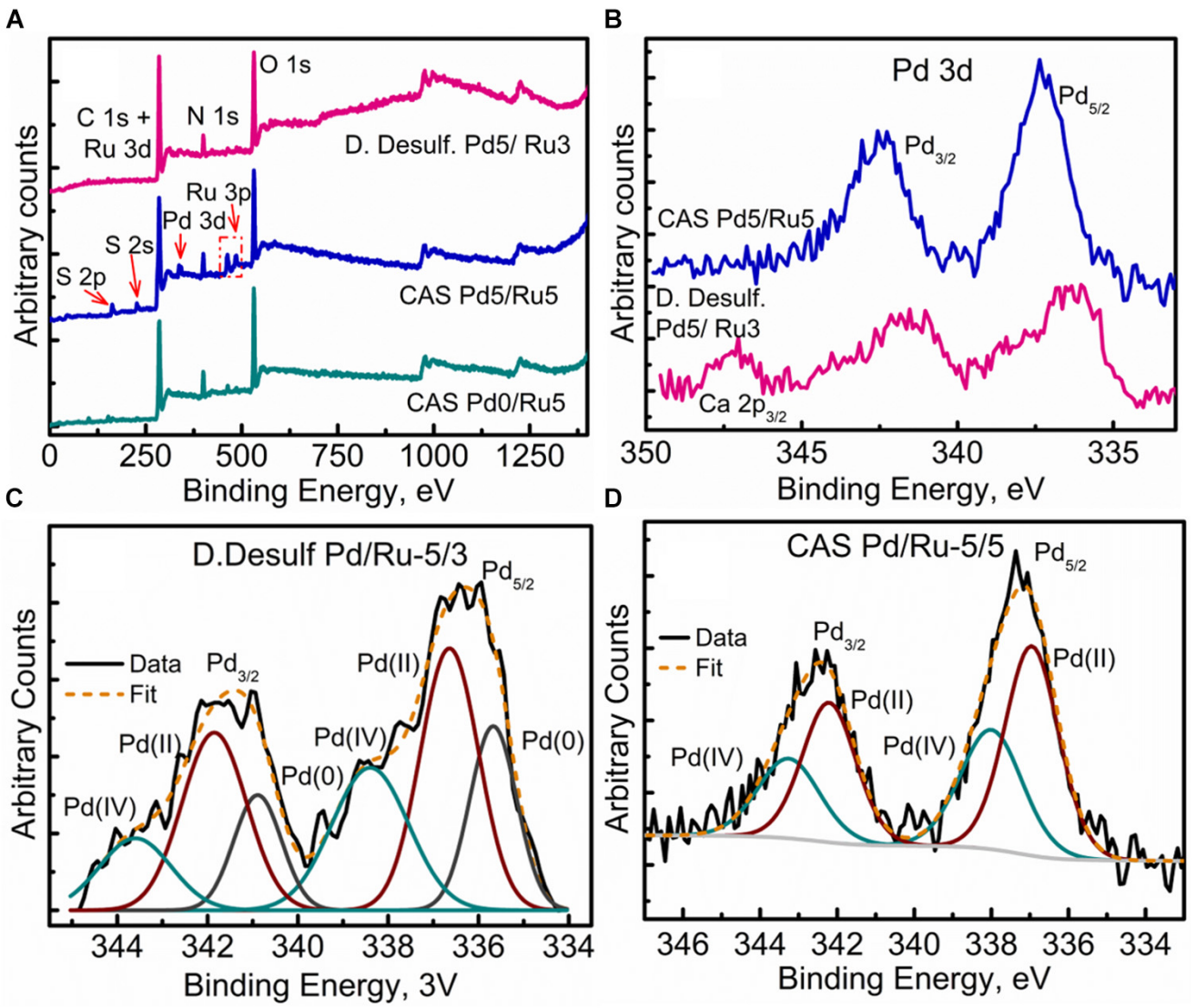

FIGURE 8 | XPPS analysis showing (A) Wide energy survey spectra for the metalized bacterial samples, (B) High-resolution Pd $3 d$ comparison for the two bimetallic samples, (C) Pd 3d fitted components for the D. desulfuricans Pd5/Ru3 sample, and (D) Pd 3d fitted components for the CAS Pd5/Ru5 sample. 
background between the cells (Figures 6C,D). Examination of cell areas (Supplementary Figure S7) suggested that, where both elements occurred together, they tended to be co-localized, but areas of solely Pd-NPs were visible. The large Ru-NPs tended to occur as overgrowths onto Pd-NPs. While it is possible to assign a numerical correlation to the co-occurrence of specific elements in NPs (Omajali, 2015) this was not possible in the present study due to the small size and poor definition of the NPs, preventing estimation of NP boundaries (e.g., Supplementary Figure S7F).

Type II cells in the CAS showed metallic deposits mainly at the cell surface in a similar way to that described for $D$. desulfuricans (see earlier). On the basis of the lattice fringes (see earlier) metal sulfides could not be discounted; even though the cells were washed a faint odor of $\mathrm{H}_{2} \mathrm{~S}$ was detected in the CAS on standing after a few days. As no exogenous sulfate was provided this $\mathrm{H}_{2} \mathrm{~S}$ may have arisen due to protein turnover; the presence of cellular storage materials to provide metabolic energy for turnover in the resting cells was not sought. However, given that the CAS was a mixed culture consortium evolved over 5 years, the possibility of cross-feeding may provide an evolutionary advantage under nutritionally sparse conditions, e.g., the presence of sulfide-oxidizing bacteria Acidithiobacillus ferrooxidans, which accounted for $7 \%$ of the culture (Table 2) would likely generate oxidized sulfur species for re-reduction into metal-accessible sulfides. These could arise from thiols arising from protein degradation, from cellular molecules such as glutathione or from histone proteins released from DNA during senescence. Alternatively (or in addition), given that polysulfides are now reported as cellular stores of sulfur in sulfide oxidizing bacteria and almost all of the sulfide in the reported case was oxidized to sulfate under low sulfide-flux conditions (Berg et al., 2014) there is a strong possibility that endogenous $\mathrm{H}_{2} \mathrm{~S}$ may be generated from within the culture (via nascent $\mathrm{SO}_{4}{ }^{2-}$ ) under "resting" conditions via inter-species turnover. In addition, Newman et al. (1997) reported that Desulfotomaculum (a sulfatereducer) precipitated arsenic trisulfide. The ability of bacteria to store sulfur is well recognized (e.g., Pickering et al., 2001; Pickering and George, 2002). In this case the storage material comprised globules of sulfur and not polysulfide (Pickering and George, 2002). Elemental mapping (Figure 7) showed colocalization of palladium and sulfur with a greater density of sulfur in the CAS sample as compared to D. desulfuricans, which had no access to additional oxidized forms of sulfur to reduce to thiols $/ \mathrm{H}_{2} \mathrm{~S}$ during NP formation. Although the EDX mapping method is qualitative only the result was confirmed in hydrated samples by complementary X-ray mapping (below). As far as the authors are aware, this is the first report of potential bacterial sulfur cycling being harnessed to the generation of novel catalytic biomaterials.
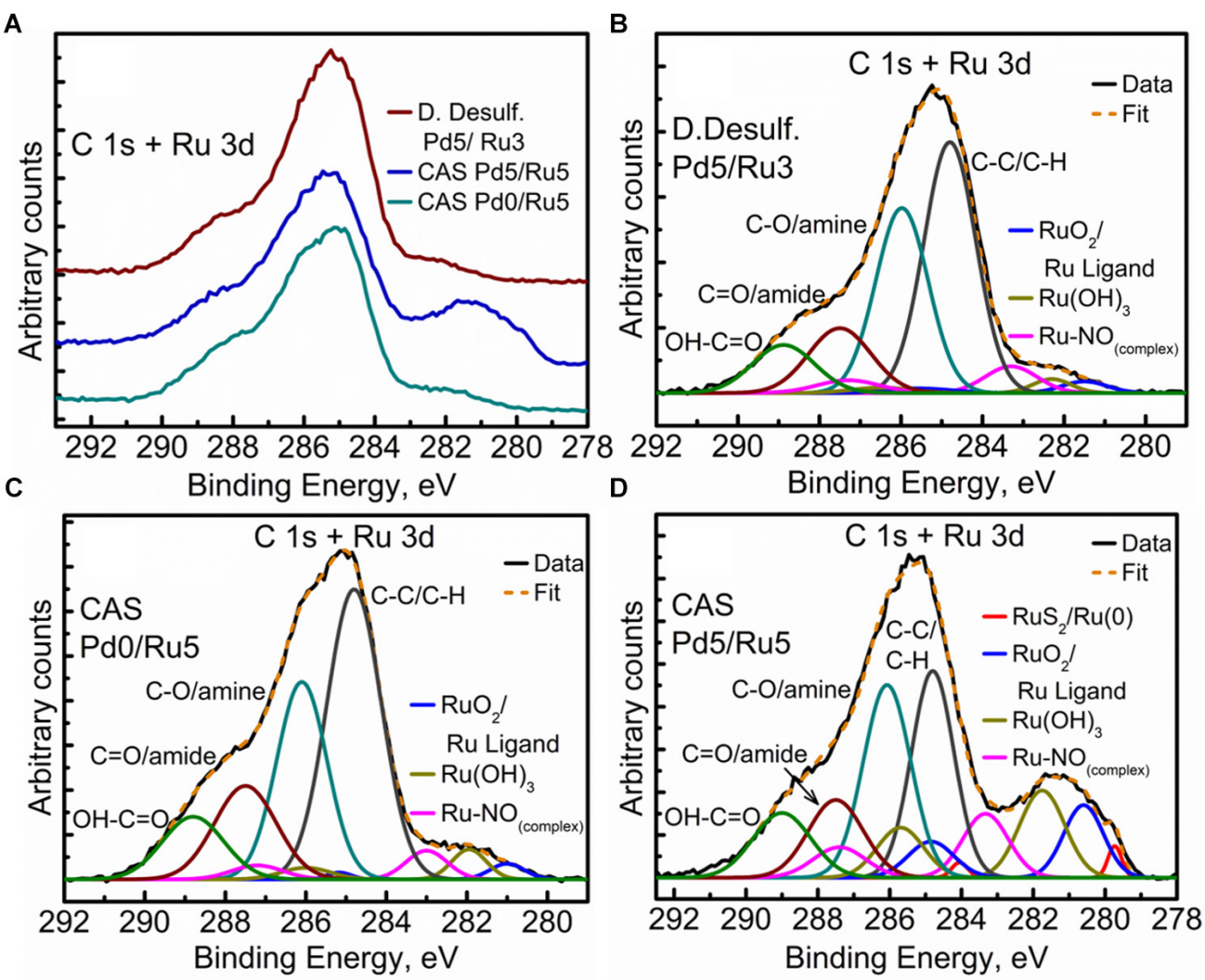

FIGURE 9 | High Resolution C 1s + Ru 3d spectra showing (A) comparison of the three metallized bacterial samples, (B) fitted components for the D. desulfuricans Pd5/Ru3 sample, (C) fitted components for the CAS Pd0/Ru5 sample, and (D) fitted components for the CAS Pd5/Ru5 sample. 


\section{Co-localization of Pd, Ru, and S Using $X-R a y$ Mapping of Hydrated Specimens of CAS}

Synchrotron radiation based scanning X-ray microscopy was used to determine the distribution of chemical elements (e.g., Pd, S) within the metallic NPs produced by hydrated specimens of CAS. XRF elemental mapping analysis was carried out at $\mathrm{K}$ and $\mathrm{L}$ edge of $\mathrm{S}$ and $\mathrm{Pd}$, respectively. The results obtained (Supplementary Figure S7B) showed a close association of S and $\mathrm{Pd}$ at microscale (size of the analyzed region was $20 \mu \mathrm{m} / 70 \mu \mathrm{m}$ ). This microscale analysis is complemented by that of the EDX mapping method of the STEM/HAADF system. The major limitation of the EDX mapping method is that, while it is specific for the elements of interest (as long as their X-ray emission peaks are well separated) and can measure accurately most elements (but not the light elements like N, C) only a few cells can be examined within a field of view, albeit with mapping of specimen microareas within a single cell. In contrast the sensitivity of mapping X-ray emissions under illumination by synchrotron radiation is greater than from EDX and can co-map the light elements but this method has a limit of resolution of about 20 microns and hence it can best image cell clusters in a given field of view and provide a numerical analysis of "population" cooccurrence; this then takes into account the presence of different cell types. The first images confirm co-localization of Pd and S by this method, where the areas of high $\mathrm{Pd}$ and $\mathrm{S}$ correspond to single cells (Supplementary Figure S7B); numerical analysis of the data to gain whole-population correlations of co-localization of $\mathrm{Pd}, \mathrm{Ru}$ as well as $\mathrm{S}, \mathrm{P}$, and $\mathrm{N}$ is in progress.

\section{Analysis of Cell Surfaces by X-Ray Photoelectron Spectroscopy (XPS)}

XPS analysis was carried out on the metallized $D$. desulfuricans (Pd5\%/Ru3\%) and the metallized CAS samples (Pd0\%/Ru5\% and Pd5\%/Ru5\%). Wide energy survey spectra recorded for the three types of samples (Figure 8A) identified the presence of $\mathrm{C} 1 \mathrm{~s}+\mathrm{Ru} 3 \mathrm{~d}$ along with $\mathrm{N} 1 \mathrm{~s}, \mathrm{O} 1 \mathrm{~s}$ and $\mathrm{S} 2 \mathrm{p}$. In addition, a small signature of $\mathrm{Pd} 3 \mathrm{~d}$ and $\mathrm{Ru} 3 \mathrm{p}$ was also noted for the $D$. desulfuricans material. In the CAS samples, apart from the above, $S 2 s$ and $S 2 p$ were identified. Bimetallic CAS consisted of a higher sulfur content (3.55 at\%) than CAS (Ru5\%), which revealed 1.18 at\% sulfur content (see Table 3) from the elemental composition obtained from XPS, despite the similar wash procedures applied in each case. The production of $\mathrm{H}_{2} \mathrm{~S}$ by washed, resting cells was not quantified but may have arisen from protein turnover/degradation as sulfate was not supplied to the resting cell suspensions (see above Discussion). Bimetallic CAS also confirmed the presence of Pd, identified as $\mathrm{Pd} 3 \mathrm{~d}$ as well as a higher $\mathrm{Ru}(\mathrm{Ru} 3 \mathrm{p})$ content. Further detailed analysis of the elements and their chemical interactions was carried out
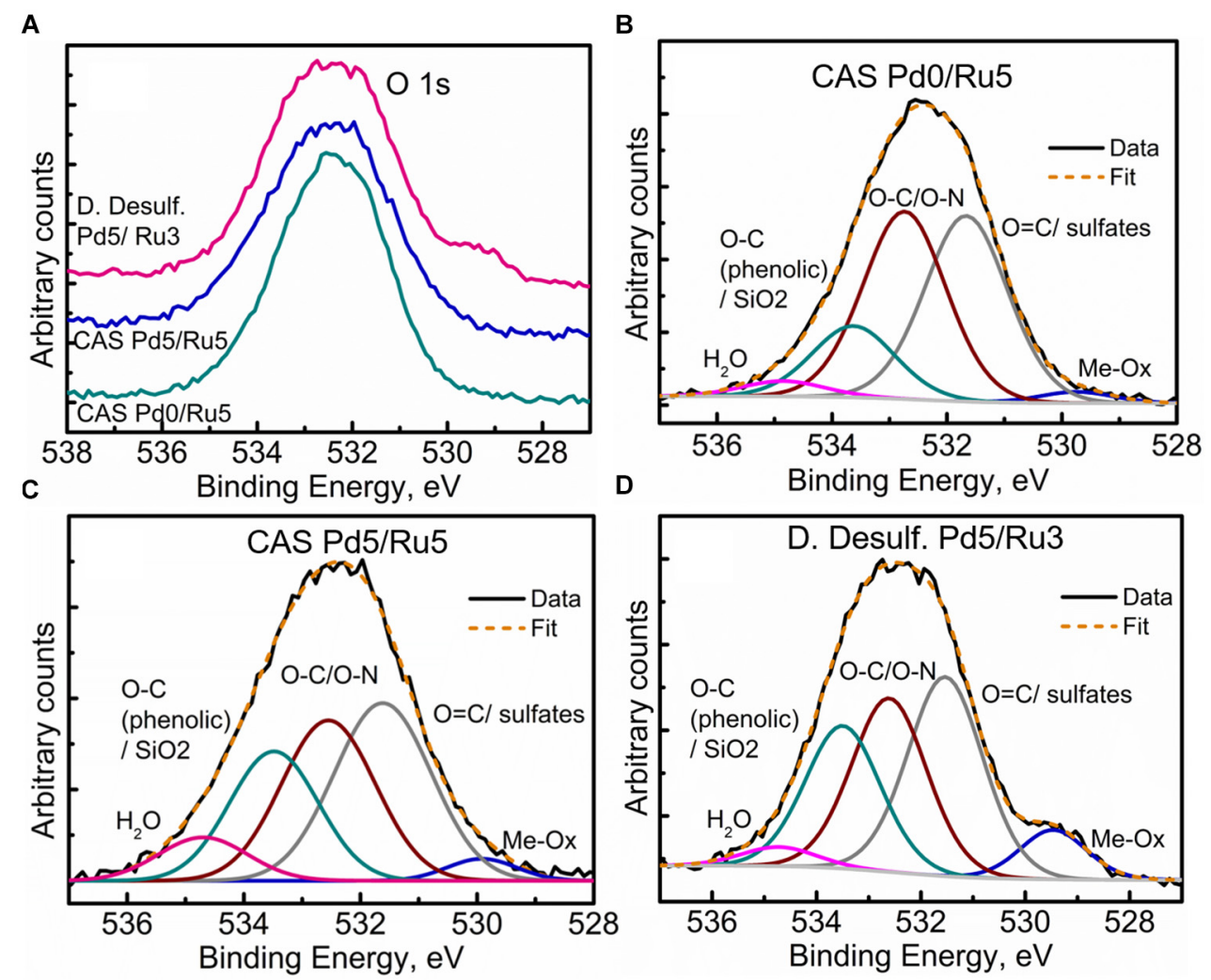

FIGURE 10 | High Resolution O 1s spectra showing (A) comparison of the three metallized bacterial samples, (B) fitted components for the CAS Pd0/Ru5 sample, (C) fitted components for the CAS Pd5/Ru5 sample fitted, and (D) components for the D. desulfuricans Pd5/Ru3 sample. 
using high-resolution spectra collected for all these elements. A comparison of the high resolution Pd $3 \mathrm{~d}$ spectra for the two bimetallic systems revealed (Figure 8B) broader doublet peaks for D. desulfuricans centered at 336 and $341 \mathrm{eV}$. The CAS sample, on the other hand, revealed a sharper doublet peak shifted to higher binding energy $(337,342 \mathrm{eV})$. Deconvolution of the two spectra into respective components can be seen in Figures $\mathbf{8 C}, \mathbf{D}$, respectively. D. desulfuricans samples consisted of $\mathrm{Pd}$ in its metallic [Pd (0)] as well as oxidized forms [Pd(II) and $\mathrm{Pd}(\mathrm{IV})]$, while the bimetallic CAS with its spectra shifted to higher binding energies suggested a complete absence of metallic $\mathrm{Pd}$ and consisted of Pd only in its oxidized forms. The presence of palladium sulfides $\left(\mathrm{Pd}_{\mathrm{x}} \mathrm{S}_{\mathrm{y}}\right)$ which may have been formed due to exposure of $\mathrm{H}_{2} \mathrm{~S}$ during the growth of NPs cannot be ruled out in this case. This would further justify the shift in the Pd spectra and explain the complete absence of $\mathrm{Pd}$ in its metallic form (unlike previous reports on bioPd), whereby any unoxidized Pd NPs were "claimed" by the sulfur. The signature binding energies for $\left(\mathrm{Pd}_{\mathrm{x}} \mathrm{S}_{\mathrm{y}}\right)$ in the high resolution $\mathrm{Pd}$ spectra are similar to those of oxidized $\mathrm{Pd}(\mathrm{Xu}$ et al., 2013) and therefore, could not be identified as separate components here.

The high resolution $\mathrm{C} 1 \mathrm{~s}+\mathrm{Ru} 3 \mathrm{~d}$ spectra for the three samples are compared in Figure 9A (comparison of $\mathrm{Ru} 3 \mathrm{p}$ spectra can be seen in Supplementary Figure S8). Here again, bimetallic CAS shows a significantly larger "bump" with a peak centered near $281 \mathrm{eV}$, attributable to the higher amount of Ru content as compared to other two samples. It must be noted that the $\mathrm{Ru}$ $3 \mathrm{~d}_{5 / 2}$ region extends to $279 \mathrm{eV}$ in case of bimetallic CAS unlike D. desulfuricans and Ru-only CAS where the signal was observed only up to $280 \mathrm{eV}$. Component peaks for the three samples can be seen in the deconvoluted spectra in Figures 9B-D. Components identified in the three spectra were similar to those reported in similar bacterial systems reported earlier (Priestley et al., 2015; Gomez-Bolivar et al., in review). In the case of bimetallic CAS, the extended $\mathrm{Ru} 3 \mathrm{~d}_{5 / 2}$ region (in which the $\mathrm{Ru}$ components are more easily identifiable compared to $\mathrm{Ru} 3 \mathrm{~d}_{3 / 2}$ which is overshadowed by $\mathrm{C} 1 \mathrm{~s}$ components), suggested the presence of an additional $\mathrm{Ru}$ component near $279.7 \mathrm{eV}$. This component is close to the binding energy (BE) of metallic $\mathrm{Ru}$ and $\mathrm{RuS}_{2}$. The component is more likely $\mathrm{RuS}_{2}$ in this case given: (i), the presence of $\mathrm{H}_{2} \mathrm{~S}$ produced by the bacteria during the NP synthesis; (ii), metallic $\mathrm{Ru}$ is highly unlikely to be present in the oxidizing environment near the surface layers of the bacteria given its oxophilic nature, as reported previously (Gomez-Bolivar et al., in review; this volume), and (iii), this is agreement with the presence of sulfide in the Pd (and S2p) spectra, emphasizing the sulfidation of the available metal NPs taking place in this system.

Further clarity in the sulfidation/oxidation of the metal NP in these bacterial systems was attained with the help of highresolution $\mathrm{O}$ 1s spectra for the three systems (Figures 10A-D). A simple comparison of the high resolution $\mathrm{O}$ 1s spectra (Figure 10A) revealed a clear shoulder below $530 \mathrm{eV}$ in the bimetallic $D$. desulfuricans, suggesting a higher metal oxide content. The deconvolution of the three spectra revealed typical peaks attributed to metal oxide $(\mathrm{Me}-\mathrm{Ox}), \mathrm{O}=\mathrm{C} /$ sulfate, $\mathrm{O}-\mathrm{C} / \mathrm{O}-\mathrm{N}$, phenolic $\mathrm{O}-\mathrm{C} / \mathrm{SiO}_{2}$, and adsorbed $\mathrm{H}_{2} \mathrm{O}$. As seen in Figure 10D, the Me-Ox component for bimetallic D. desulfuricans in $\mathrm{O}$ 1s spectra has a much higher contribution as compared to that in the other two samples. Looking back at the elemental compositions, the atomic \% of oxygen and ruthenium was similar in the material of $D$. desulfuricans and Ru-CAS (Table 3) yet $D$. desulfuricans has higher Me-Ox component. Bimetallic CAS consisted of a slightly higher $\mathrm{Ru}$ content than the other two samples along with a higher S content. Hence, it can be concluded that the CAS samples must consist of Me-Ox as well as metal sulfides (for $\mathrm{Pd}$ and $\mathrm{Ru}$ ) and that metallic $\mathrm{Ru}$ is unlikely to be present in the surface layers of the bacterial systems observed in the XPS.

High-resolution $S 2 p$ spectra are seen in Figures 11A-C (see Supplementary Figure $\mathbf{S} 9$ for comparison of $2 p$ spectra).

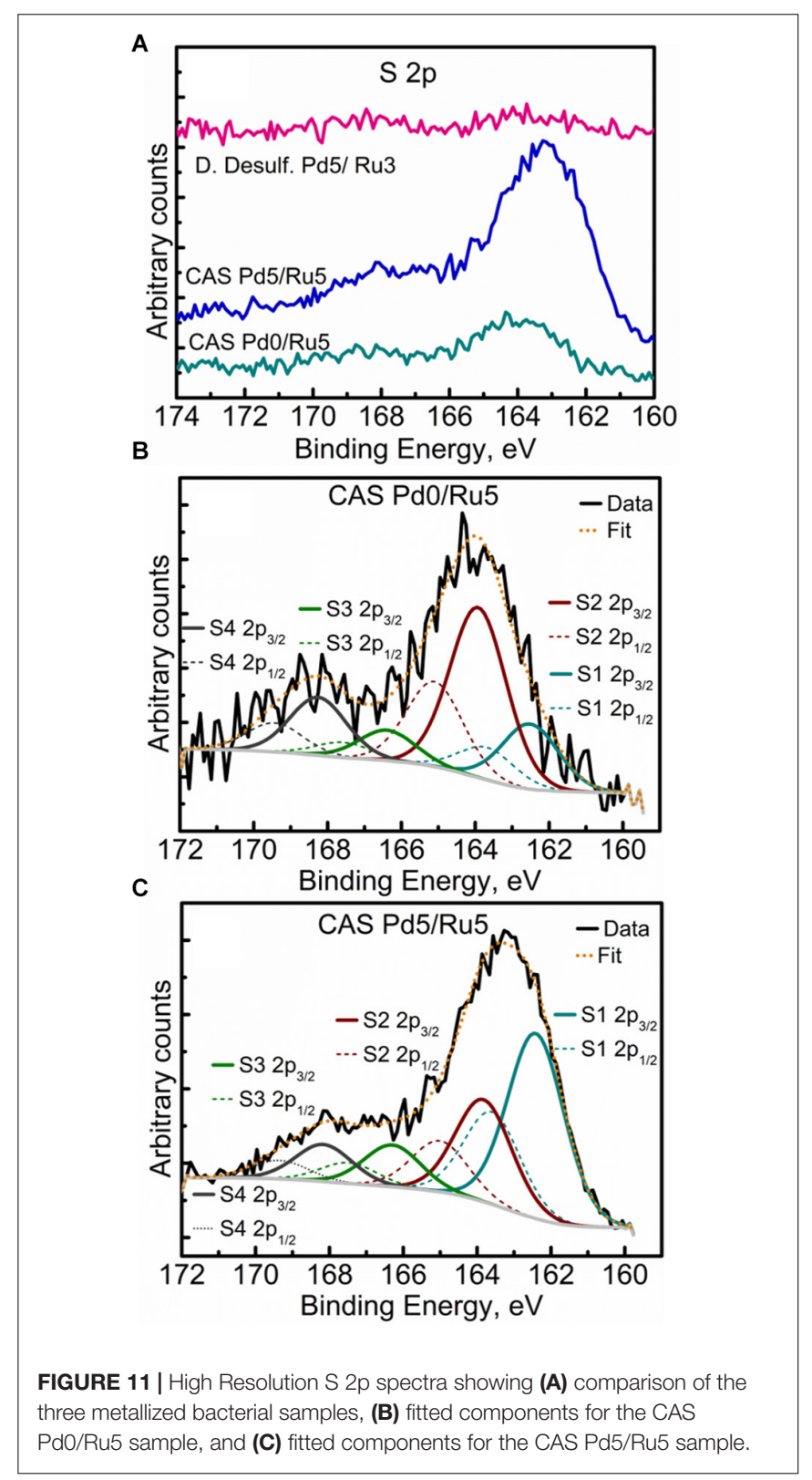


TABLE 4 | Binding energies for the components identified in sulfur spectra along with peak attributions.

\begin{tabular}{|c|c|c|c|c|}
\hline \multirow[t]{3}{*}{ Component } & \multicolumn{2}{|c|}{ Binding Energy, eV } & \multirow[t]{3}{*}{ Attributions } & \multirow[t]{3}{*}{ References } \\
\hline & CAS & CAS & & \\
\hline & Ru 5\% & Pd5\%/Ru5\% & & \\
\hline S1 & $162.5,163.7$ & $162.5,163.8$ & $\mathrm{RuS}_{2}, \mathrm{Pd}_{\mathrm{x}} \mathrm{S}_{\mathrm{y}}$ & De Los Reyes et al., 1990; Love et al., 2003 \\
\hline S2 & $163.9,165.1$ & $163.9,165.1$ & $-\mathrm{S}-\mathrm{S}-, \mathrm{S}=\mathrm{C}=\mathrm{S},-\mathrm{S}-\mathrm{CH}_{3}$ & Lindberg et al., 1970; Love et al., 2003 \\
\hline S3 & $166.3,167.5$ & $166.4,167.6$ & $\mathrm{SO}_{2}-\mathrm{Na}$, aromatic -C-S-O-, & Lindberg et al., 1970 \\
\hline S4 & $168.2,169.4$ & $168.2,169.4$ & Sulfided $\mathrm{Pd} / \mathrm{C}, \mathrm{SOCl}_{2}$ & Lindberg et al., 1970; Xu et al., 2013 \\
\hline
\end{tabular}

Bimetallic CAS sample revealed a peak centered near $163 \mathrm{eV}$ while the Ru-CAS sample showed a peak centered near $164 \mathrm{eV}$. Deconvolution of the two revealed four sets of components $(2 \mathrm{p}$ doublets, $2 \mathrm{p}_{3 / 2}$, and $2 \mathrm{p}_{1 / 2}$ ), identified as S1, S2, S3, and S4. These component peaks were identified with 2 or more attributions, as listed in Table 4. The primary reason for these multiple attributions is the complex nature of these metallized CAS and D. desulfuricans samples as well as the similar omnipresent sulfur present in the form of $\mathrm{H}_{2} \mathrm{~S}$, which was produced by the bacteria themselves. Various S-C bonds, SOx-Me bonds, and S-C-Me $(\mathrm{Me}=\mathrm{Ca}, \mathrm{Fe}, \mathrm{Na}, \mathrm{Cl}, \mathrm{F}$, i.e., trace metals naturally present in bacteria) complexes are possibly formed due to the interactions between polymeric/aliphatic/aromatic carbon structures within the bacterial structures and the available sulfur. The binding energies (BEs) for such bonds and complexes are very close to each other and hence single attributions to thee sulfur components cannot be identified in these systems. Similarly, the BEs for $\mathrm{RuS}_{2}$ and $\mathrm{Pd}_{\mathrm{x}} \mathrm{S}_{\mathrm{y}}$ are also close to reach other and components cannot be identified individually. Interestingly, bimetallic CAS with higher S at\%, appears to have a higher metal sulfide component $\mathrm{S} 1$ which is in agreement with the $\mathrm{Ru} 3 \mathrm{~d}$ and Pd 3d spectra.

\section{CONCLUSION}

This study shows clear potential for the harnessing of biomass waste side-streams into additional energy materials (via bioNP catalysts) to help offset the "parasitic" energy demand of biomass comminution and hydrothermal processing. A common solvent allowed a single stage processing, extraction and catalytic upgrading of 5- HMF to make DMF, a "drop in" fuel. Commercial catalyst, although effective in upgrading of commercial 5-HMF, had low activity against 5-HMF derived from thermochemical processing of starch and cellulose. $\mathrm{Pd} / \mathrm{Ru}$ bimetallic nanoparticles made and supported on bacterial cells were effective in this reaction. Waste sulfidogenic bacteria from another, unrelated, biotechnology process outperformed the "classical" sulfidogen D. desulfuricans. This may be attributed to the higher $\mathrm{Ru}$ content of the bimetallic of the former but could equally well be assigned to the higher proportion of metal sulfides formed in resting cells of the bacterial consortium without exogenous oxidized sulfur species. The role of palladium sulfide ensembles as enhanced hydrogenation catalysts is just emerging in the literature; as yet a role is not assigned for ruthenium sulfides in hydrogenation such as we suggest. The contributory roles of $\operatorname{Pd}(0)$ and oxidized $\mathrm{Pd}$ species, palladium sulfides and the various species of $\mathrm{Ru}$ (III) (IV) (VI) and $\mathrm{RuS}_{2}$, await further elucidation via advanced characterization methods. However, the use of mixed metal NPs opens new opportunities for using metals recovered for wastes, as waste streams rarely contain single metals; neo-catalyst bio-genesis from waste is now well established in other published work.

\section{AUTHOR CONTRIBUTIONS}

Biomaterials were made and characterized by JG-B and IM. RO developed the method for 5-HMF extraction from hyrolyzates and common reaction solvent system and made the energy balance calculations. RO and JG-B did catalytic testing, with analysis of products by $\mathrm{RH}$. SEM and high resolution TEM/elemental mapping were done by JG-B and MM. XPS data acquisition was done by MW with XPS interpretations by MW and SS. Synchrotron measurements were done by MM, IM, and LM with interpretation by MM. DJ and BG maintained the SCW culture and provided the samples of CAS for use in this study. The paper was authored by LEM with contributions from all authors.

\section{FUNDING}

This project was funded by NERC grant NE/L014076/1 to LM (Program: "Resource Recovery from Wastes"). The Science City Photoemission Facility used in this research was funded through the Science Cities Advanced Materials Project 1: "Creating and Characterizing Next Generation of Advanced Materials" with support from AWM and ERDF funds. The microscopy work was conducted at "Centro de Instrumentación Cientifica" at the University of Granada, Spain. This work was partially supported by the Spanish Government Sistema Nacional de Grantia Juvenil grant PEJ-2014-P-00391 (Promocion de Empleo Joven e Implantacion de la Garantia Juvenil 2014, MINECO) with a scholarship to JG-B.

\section{ACKNOWLEDGMENTS}

The authors acknowledge with thanks, use of GC-FID/GCMS supplied by Dr. Daniel Lester within the Polymer Characterization Research Technology Platform, University of Warwick and the help of Drs. B. Kaulich, T. Araki, 
and M. Kazemian at beamline IO8, Diamond Light Source, United Kingdom, who funded the synchrotron study (Award No. SP16407: Scanning X-ray Microscopy Study of Biogenic Nanoparticles; Improved Bionanocatalysts by Design) on I08 Scanning X-ray Microscopy beamline (SXM).

\section{REFERENCES}

Al-Amin, A. Q., Rasiah, R., and Chenayah, S. (2015). Prioritizing climate change mitigation: an assessment using Malaysia to reduce carbon emissions in future. Environ. Sci. Policy 50, 24-33. doi: 10.1016/j.envsci.2015.02.002

Albani, D., Shahrokhi, M., Chen, Z., Mitchell, S., Hauert, R., López, N., et al. (2018). Selective ensembles in supported palladium sulfide nanoparticles for alkyne semi-hydrogenation. Nat. Commun. 9:2634. doi: 10.1038/s41467-018-05052-4

Aycock, D. F. (2007). Solvent applications of 2-methyltetrahydrofuran in organometallic and biphasic reactions. Org. Proc. Res. Dev. 11, 156-159. doi: 10.1021/op060155c

Bartolome, J., Bartolome, F., García, L. M., Figueroa, A. I., Repolles, A., Martínez, M. J., et al. (2012). (2012) Strong magnetism of Au nanoparticles deposited on Sulfolobus acidocaldarius S-layer. Phys. Rev. Lett. 109, 247203-247203. doi: 10.1103/PhysRevLett.109.247203

Berg, J. S., Schwedt, A., Kreutzmann, A.-C., Kuypers, M. M. M., and Miluckaa, J. (2014). Polysulfides as intermediates in the oxidation of sulfide to sulfate by Beggiatoa spp. Appl. Environ. Microbiol. 80, 629-636. doi: 10.1128/AEM.0285213

Beveridge, T. J. (1989). Role of cellular design in bacterial metal accumnulaiton and mineralization. Ann. Rev. Microbiol. 43, 147-171. doi: 10.1146/annurev.mi.43. 100.189.001051

Blumenthal, L. C., Jens, C. M., Ulbrich, J., Schwering, F., Langrehr, V., Turek, T., et al. (2016). Systematic identification of solvents optimal for the extraction of 5 hydroxymethylfurfural from aqueous reactive solutions. ACS Sust. Chem. Eng. 4, 228-235. doi: 10.1021/acssuschemeng.5b01036

Cadez, S., and Czerny, A. (2016). Climate change mitigation strategies in carbonintensive firms. J. Cleaner Prodn. 112, 4132-4143. doi: 10.1016/j.jclepro.2015. 07.099

Charlot, G. (1978). Dosages Absorptiométriques des Eléments Mineraux, 2nd Edn. Paris: Masson.

Chu, S., and Majumdar, A. (2012). Opportunities and challenges for a sustainable energy future. Nature 488, 294-303. doi: 10.1038/nature11475

Da Silva, J. R., and Aznar, M. (2014). Thermophysical properties of 2,5dimethylfuran and liquid-liquid equilibria of ternary systems water $+2,5$ dimethylfuran + alcohols (1-butanol or 2-butanol or 1-hexanol). Fuel 136, 316-325. doi: 10.1016/j.fuel.2014.07.039

Dang, Q., Hu, W., Rover, M., Brown, R. C., and Wright, M. M. (2016). Economics of biofuels and bioproducts from an integrated pyrolysis biorefinery. Biofuel. Bioprod. Bioref. 10, 790-803. doi: 10.1002/bbb.1681

De Los Reyes, J. A., Gidbolos, S., Vrinat, M., and Breysse, M. (1990). Preparation and characterization of highly active ruthenium sulphide supported catalysts. Catal. Lett. 5, 17-24. doi: 10.1007/BF00772089

De Vries, Y. P. (2004). The role of calcium in bacterial; spore germination. Microbes Environ. 19, 199-202. doi: 10.1264/jsme2.19.199

Deplanche, K., Bennett, J. A., Mikheenko, I. P., Omajali, J., Wells, A. S., Meadows, R. E., et al. (2014). Catalytic activity of biomass-supported Pd nanoparticles: influence of the biological component in catalytic efficacy and potential application in 'green' synthesis of fine chemicals and pharmaceuticals. Appl. Catal. B Environ. 147, 651-665. doi: 10.1016/j.apcatb.2013.09.045

Deplanche, K., Caldelari, I., Mikheenko, I. P., Sargent, F., and Macaskie, L. E. (2010). Involvement of hydrogenases in the formation of highly catalytic $\operatorname{Pd}(0)$ nanoparticles by bioreduction of $\mathrm{Pd}(\mathrm{II})$ using Escherichia coli mutant strains. Microbiology 156, 2630-2640. doi: 10.1099/mic.0.036681-0

Deplanche, K., Merroun, M. L., Casadesus, M., Tran, D. T., Mikheenko, I. P., Bennett, J. A., et al. (2012). Microbial synthesis of core/shell gold/palladium nanoparticles for applications in green chemistry. J. Roy. Soc. Interface 9, 1705-1712. doi: 10.1098/rsif.2012.0003

Divakar, R., and Raghunathan, V. S. (2003). Characterisation of interfaces in nanocrystalline palladium. Sadhana 28, 47-62. doi: 10.1007/BF02717125

\section{SUPPLEMENTARY MATERIAL}

The Supplementary Material for this article can be found online at: https://www.frontiersin.org/articles/10.3389/fmicb. 2019.00970/full\#supplementary-material

Dogaris, I., Karapati, S., Mamma, D., Kalogeris, E., and Kekos, D. (2009). Hydrothermal processing and enzymatic hydrolysis of sorghum bagasse for fermentable carbohydrates production. Biores. Technol. 100, 6543-6549. doi: 10.1016/j.biortech.2009.07.046

Dunleavy, J. K. (2006). Sulfur as a catalyst poison. Plat. Met. Rev. 50, 110-110. doi: 10.1595/147106706X111456

Ezeji, T., Qureshi, N., and Blaschek, H. P. (2007). Butanol production from agricultural residues: impact of degradation products on Clostridium beijerinckii growth and butanol fermentation. Biotechnol. Bioeng. 97, 14601469. doi: 10.1002/bit.21373

Fairley, N. (2013). Available at: www.casaxps.com

Gawade, A. B., Tiwari, M. S., and Yadav, G. D. (2016). Biobased green process: selective hydrogenation of 5-hydroxymethylfurfural to 2,5-dimethyl furan under mild conditions using Pd-Cs2.5H0.5PW12O40/K-10 ClayACS. Sustain. Chem. Eng. 4, 4113-4123. doi: 10.1021/acssuschemeng.6b00426

Gollakota, A. R. K., Kishore, N., and Gu, S. (2018). A review on hydrothermal liquefaction of biomass. Renew. Sust. En. Rev. 81, 1378-1392. doi: 10.1016/j. rser.2017.05.178

Gotterbarm, K. M., Luckas, N., Hoefert, O., Lorenz, M. P. A., Streber, R., Papp, C., et al. (2012). Kinetics of the sulfur oxidation on palladium; a combined in situ $\mathrm{x}$-ray photoelectron spectroscopy and density-functional study. J. Chem. Phys. 136:094702. doi: $10.1063 / 1.3687676$

Govindan, K., and Hasanagic, M. (2018). A systematic review on drivers, barriers, and practices towards circular economy: a supply chain perspective. Int. J. Prodn. Res. 56, 278-311. doi: 10.1080/00207543.2017.1402141

Haldar, D., Sen, D., and Gayen, K. (2016). A review on the production of fermentable sugars from lignocellulosic biomass through conventional and enzymatic route-a comparison. Int. J. Green En. 13, 1232-1253. doi: 10.1080/ 15435075.2016.1181075

Hansen, T. S., Barta, K., and Anastas, P. T. (2012). One-pot reduction of 5hydroxymethylfurfural via hydrogen transfer from supercritical methanol. Green Chem. 14, 2457-2461. doi: 10.1039/C2GC35667H

Hodge, D. B., Anderson, C., Berglund, K. A., and Rova, U. (2009). Detoxification requirements for bioconversion of softwood dilute acid hydrolyzates to succinic acid. Enz. Microb. Technol. 44, 309-316. doi: 10.1016/j.enzmictec. 2008. 11.007

Hu, L., Tang, X., Xu, J., Wu, Z., Lin, L., and Liu, S. (2014). Selective transformation of 5-hydroxymethylfurfural into the liquid fuel 2,5dimethylfuran over carbonsupported ruthenium. Ind. Eng. Chem. Res. 53, 3056-3064. doi: 10.1021/ ie404441a

Jin, H., Li, Y., Liu, X., Ban, Y., Peng, Y., Jiao, W., et al. (2015). Recovery of HMF from aqueous solution by zeoliticimidazolate frameworks. Chem. Eng. Sci. 124, 170-178. doi: 10.1016/j.ces.2014.07.017

Kamio, E., Takahashi, S., Noda, H., Fukuhara, C., and Okamura, T. (2006). Liquefaction of cellulose in hot compressed water under variable temperatures. Ind. Eng. Chem. Res. 45, 4944-4953. doi: 10.1021/ie0 $60136 \mathrm{r}$

Kunwar, B., Deilami, S. D., Macaskie, L. E., Wood, J., Biller, P., and Sharma, B. K. (2017). Nanoparticles of palladium supported on bacterial biomass for hydroprocessing bio oil from continuous hydrothermal liquefaction (NTL) of algae. Fuel 209, 449-456. doi: 10.1016/j.fuel.2017. 08.007

Lei, H., Tang, X., Xu, J., Wu, Z., Lu, L., and Liu, S. (2014). Selective transformation of 5-hydroxymethylfurfural into the liquid fuel 2,5-dimethylfuran over carbonsupported ruthenium. End. Eng. Chem. Res. 53, 3056-3064. doi: 10.1021/ ie404441a

Lindberg, B. J., Hamrin, I. K., Johansson, G., Gelius, U., Fahlman, A., Nordling, A. C., et al. (1970). Molecular spectroscopy by means of ESCA II.sulfur compounds. Correlation of electron binding energy with structure. Phys. Scripta 1, 286-298. doi: 10.1088/0031-8949/1/5-6/020 
Liu, Y., Mellmer, M. A., Alonso, D. M., and Dumesic, J. A. (2015). Effects of water on the copper-catalyzed conversion of hydroxymethyl furfural in tetrahydrofuran. Chem. Sus. Chem. 8, 3983-3986. doi: 10.1002/cssc.201501122

Love, J. C., Wolfe, D. B., Haasch, R., Chabinyc, M. L., Paul, E., Whitesides, G. M., et al. (2003). Formation and structure of self-assembled monolayers of alkanethiolates on palladium. J. Am. Chem. Soc. 125, 2597-2609. doi: 10.1021/ ja028692

Lu, Y. J., Guo, L. J., and Zhang, X. M. (2006). Thermodynamic modeling and analysis of hydrogen production process by biomass gasification in supercritical water. Abstr. Pap. Am. Chem. Soc. 2006:231.

Luo, W., Sanker, M., Beale, A. M., He, Q., Kiely, C. J., Bruijnincx, P. C. A., et al. (2015). High performing and stable supported nano-alloys for the catalytic hydrogenation of levulinic acid to gamma- valerolactone. Nat. Commun. 6:6540. doi: 10.1038/ncomms7540

Ma, H., Ji, X., Tian, Z., Fang, G., and Yang, G. (2017). Adsorption removal of inhibiting compounds by modified activated carbon. J. Energ. Nat. Res. 6, 24-30. doi: 10.11648/j.jenr.20170602.12

Merroun, M. L., Raff, J., Rossberg, A., Hennig, C., Reich, T., and Selenska-Pobell, S. (2005). Complexation of uranium by cells and S-layer sheets of Bacillus sphaericus JG-A12. Appl. Environ. Microbiol. 71, 5542-5553. doi: 10.1128/AEM. 71.9.5532-5543.2005

Merroun, M. L., Rossberg, A., Hennig, C., Scheinost, A. C., and SelenskaPobell, S. (2007). Spectroscopic characterization of gold nanoparticles formed by cells and S-layer protein of Bacilus sphaericus JG-A12. Mat. Sci. Eng. C Biomimetic Supramol. Syst. 27, 188-192. doi: 10.1016/j.msec.2006. 05.001

Miao, Z., Grift, T. E., Hansen, A. C., and Ting, K. C. (2011). Energy requirement for comminution of biomass in relation to article physical properties. Ind. Crops Prod. 33, 508-513. doi: 10.1016/j.indcrop.2010.12.016

Minowa, Z. F., Tomoko, O. G. I., and Varheghyi, G. (1998). Decomposition of cellulose and glucose in hot-compressed water under catalyst-free condtitions. J. Chem. Eng. Jap. 31, 131-134. doi: 10.1252/jcej.31.131

Mitra, J., Zhou, X., and Rauchfuss, T. (2015). Pd/C-catalyzed reactions of HMF: decarbonylation, hydrogenation, and hydrogenolysis. Green Chem. 17, 307313. doi: 10.1039/C4GC01520G

Miyazawa, T.-F. (2005). Polysaccharide hydrolysis accelerated by adding carbon dioxide under hydrothermal conditions. Biotechnol. Progr. 21, 1782-1785. doi: $10.1021 / \mathrm{bp} 050214 \mathrm{q}$

Modenbach, A. A., and Nokes, S. E. (2013). Enzymatic hydrolysis of biomass at high-solids loadings: a review. Biomass Bioeng. 56, 526-544. doi: 10.1016/j. biombioe.2013.05.031

Murray, A. J., Mikheenko, I. P., Deplanche, K. J. B., Gomez-Bolivar, J., Merroun, M. L., and Macaskie, L. E. (2019). "Biorefining of metallic wastes into new nanomaterials for green chemistry, environment and energy," in Resource Recovery from Wastes: Towards a Global Circular Economy, eds L. E. Macaskie, D. J. Sapsford, and W. M. Mayes (London: Royal Society of Chemistry).

Murray, A. J., Zhu, J., Wood, J., and Macaskie, L. E. (2017). A novel biorefinery: biorecovery of precious metals from spent automotivecatalyst leachates into new catalysts effective in metal reduction and in the hydrogenation of 2pentyne. Mins. Eng. 113, 102-108. doi: 10.1016/j.mineng.2017.08.011

Nagpure, A. S., Venugopal, A. K., Lucas, N., Manikandan, M., Thirumalaiswamy, R., and Chilukuri, S. (2015). Renewable fuels from biomass-derived compounds: Ru-containing hydrotalcites as catalysts for conversion of HMF to 2,5-dimethylfuran. Catal. Sci. Technol. 5, 1463-1472. doi: 10.1039/C4CY01376J

Nancucheo, I., and Johnson, D. B. (2012). Selective removal of transition metals from acidic mine waters by novel consortia of acidophilic sulfidogenic bacteria. Microb. Biotechnol. 5, 34-44. doi: 10.1111/j.1751-7915.2011. 00285.x

Newman, D. K., Beveridge, T. J., and Morel, F. M. M. (1997). Precipiation of arsenic trisulfide by Desulfotomaculumauripigmentum. Appl. Environ. Microbiol. 63, 2022-2028.

Nishimura, S., Ikeda, N., and Ebitani, K. (2014). Selective hydrogenation of biomass-derived 5-hydroxymethylfurfural (HMF) to 2, 5-dimethylfuran (DMF) under atmospheric hydrogen pressure over carbon supported PdAu bimetallic catalyst. Catal. Today 232, 89-98. doi: 10.1016/j.cattod.2013.10.012

Omajali, J. B. (2015). Novel Bionanocatalysts for Green Chemistry Applications. Ph.D Thesis, University of Birminham, Birminham.
Omajali, J. B., Mikheenko, I. P., Merroun, M. L., Wood, J., and Macaskie, L. E. (2015). Characterization of intracellular palladium nanoparticles synthesized by Desulfovibrio desulfuricans and Bacillus benzeovorans. J. Nanopart. Res. 17, 264-281. doi: 10.1007/s11051-015-3067-5

Orozco, R. L. (2012). Hydrogen Production From Biomass by Integrating Thermochemical and Biological Processes'. Ph.D Thesis, University of Birmingham, Birmingham.

Orozco, R. L., Redwood, M. D., Leeke, G. A., Bahari, A., Santos, R. C. D., and Macaskie, L. E. (2012). Hydrothermal hydrolysis of starch with CO2 and detoxification of the hydrolysates with activated carbon for bio-hydrogen fermentation. Int. J. Hyd. Energ. 37, 6545-6553. doi: 10.1016/j.ijhydene.2012. 01.047

Orozco, R. L., Redwood, M. D., Yong, P., Caldelari, I., Sargent, F., and Macaskie, L. E. (2010). Towards an integrated system for bio-energy: hydrogen production by Escherichia coli and Use of palladium-coated waste cells for electricity generation in a fuel cell. Biotechnol. Lett. 32, 1837-1845. doi: 10.1007/s10529010-0383-9

Palmqvist, E., and Hahn-Hägerdal, B. (2000). Fermentation of lignocellulosic hydrolysates. II: inhibitors and mechanisms of inhibition. Biores. Technol. 74, 25-33. doi: 10.1016/S0960-8524(99)00161-3

Pickering, I. J., and George, G. N. (2002). Bacterial Sulfur Storage Globules SSRL Science Highlights. Available at: https://www-ssrl.slac.stanford.edu/content/ science/highlight/2002-01-31/bacterial-sulfur-storage-globules (accessed December 13, 2018).

Pickering, I. J., George, G. N., Yu, E. Y., Brune, D. C., Tuschak, C., Overmann, J., et al. (2001). Analysis of sulfur biochemistry of sulfur bacteria using X-ray absorption spectropscopy. Biochemistry 40, 8138-8145. doi: 10.1021/bi0105532

Pillai, C. K., and Nandi, U. S. (1977). Interactions of palladium (II) with DNA. Biochim. Biophys. Acta 474, 11-16. doi: 10.1016/0005-2787(77)90209-X

Priestley, R. E., Mansfield, A., Bye, J., Deplanche, K., Jorge, A. B., Brett, D., et al. (2015). Pd nanoparticles supported on reduced graphene-E. coli hybrid with enhanced crystallinity in bacterial biomass. RSC Adv. 5, 84093-84103. doi: $10.1039 / \mathrm{c} 5 \mathrm{ra1} 2552 \mathrm{a}$

Redwood, M. D., Orozco, R. L., Majewski, A. J., and Macaskie, L. E. (2012). An integrated biohydrogen refinery: synergy of photofermentation, extractive fermentation and hydrothermal hydrolysis of food wastes. Biores. Technol. 119, 384-392. doi: 10.1016/j.biortech.2012.05.040

Roman-Leshkov, Y., Barrett, C., Liu, Z. Y., and Dumesic, J. A. (2007). Production of dimethylfuran for liquid fuels from biomass-derived carbohydrates. Nature 447, 982-985. doi: 10.1038/nature05923

Saha, B., and Abu-Omar, M. M. (2014). Advances in 5-hydroxymethylfurfural production from biomass in biphasic solvents. Green Chem. 16, 24-38. doi: 10.1039/C3GC41324A

Sánchez-Andrea, I., Stams, A. J., Hedrich, S., Ňancucheo, I., and Johnson, D. B. (2015). Desulfosporosinusacididurans sp. nov.: an acidophilic sulfate-reducing bacterium isolated from acidic sediments. Extremophiles 19, 39-47. doi: 10. 1007/s00792-014-0701-6

Santos, A. L., and Johnson, D. B. (2017). The effects of temperature and pH on the kinetics of an acidophilic sulfidogenic bioreactor and indigenous microbial communities. Hydrometall 168, 116-120. doi: 10.1016/j.hydromet.2016.07.018

Santos, A. L., and Johnson, D. B. (2018). Design and Application of a low pH upflow biofilm sulfidogenic bioreactor for recovering transition metals from synthetic waste water at a Brazilian copper mine. Front. Microbiol. 9:2015. doi: $10.3389 /$ fmicb.2018.02051

Shi, W., Gao, Y., Yang, G., and Ahao, Y. (2013). Conversion of corn stalk to biooil in hot compressed water: effects of ultrasonic pretreatment on the yield and chemical composition of bio-oil, carbon balance, and energy recovery. J. Agric. Food Chem. 61, 7574-7582. doi: 10.1021/jf401975p

Soin, N., Roy, S. S., Mitra, S. K., Thubdat, T., and McLaughlin, J. A. (2012). Nanocrystalline ruthenium oxide dispersed Few Layered Graphene (FLG) nanoflakes as supercapacitor electrodes. J. Mat. Chem. 22, 14944-14950. doi: 10.1039/C2JM31226C

Thananatthanachon, T., and Rauchfuss, T. B. (2010). Efficient production of the liquid fuel 2,5-dimethylfuran from fructose using formic acid as a reagent. Angew. Chem. 122, 6616-6618. doi: 10.1002/ange.201002267

Vardon, D. R., Sharma, B. K., Blazina, G. V., Rajagopalan, K., and Strathmann, T. J. (2012). Thermochemical conversion of raw and defatted algal biomass via 
hydrothermal liquefaction and slow pyrolysis. Biores. Technol. 109, 178-187. doi: 10.1016/j.biortech.2012.01.008

Waldron, K. J., and Robinson, N. (2009). How do bacterial cells ensure that metalloprotiens get the correct metal? Nat. Rev. Microbiol. 7, 25-35. doi: 10. 1038/nrmicro2057

Williams, A. R. (2015). Biogenic Precious Metal-Based Magnetic Nanocatalyst for Enhanced Oxygen Reduction. Ph.D Thesis, University of Birmingham, Birmingham.

Xu, W., Ni, J., Zhang, Q., Feng, F., Xiang, Y., and Li, X. (2013). Tailoring supported palladium sulfide catalysts through $\mathrm{H}+$-assisted sulfidation with H2S. J. Mater. Chem. A 1, 12811-12817. doi: 10.1039/C3TA1 $2277 \mathrm{H}$

Yang, Y., Liu, Q., Li, D., Tan, J., Zhang, Q. I., Wang, C., et al. (2017). Selective hydrodeoxygenation of 5-hydroxymethylfurfural to 2,5-dimethylfuran on $\mathrm{Ru}-\mathrm{MoO} x / \mathrm{C}$ catalysts. RSC Adv. 7, 16311-16318. doi: 10.1039/C7RA0 0605E

Yong, P., Liu, W., Zhang, Z., Beauregard, D., Johns, M. L., and Macaskie, L. E. (2015). One step bioconversion of waste precious metals into Serratia biofilmimmobilized catalyst for $\mathrm{Cr}(\mathrm{VI})$ reduction. Biotechnol. Lett. 37, 2181-2191. doi: 10.1007/s10529-015-1894-1

Yong, P., Mikheenko, I. P., Deplanche, K., Redwood, M. D., and Macaskie, L. E. (2010). Biorefining of precious metals from wastes:an answer to manufacturing of cheap nanocatalysts for fuel cells and power generation via an integrated biorefinery? Biotechnol. Lett. 32, 1821-1828. doi: 10.1007/s10529-0100378-6

Yong, P., Paterson-Beedle, M., Mikheenko, I. P., and Macaskie, L. E. (2007). From bio-mineralisation to fuel cells: biomanufacture of Pt and Pd nanocrystals for fuel cell electrode catalyst. Biotechnol. Lett. 29, 539-544. doi: 10.1007/s10529006-9283-4
Yu, D., Aihara, M., and Antal, M. J. (1993). Hydrogen Production by Steam Reforming Glucose in Supercritical Water. En. Fuels 7, 574-577. doi: 10.1021/ ef00041a002

Zaritsky, A., Rabinovitch, A., Liu, C., and Woldringh, C. L. (2017). Does the ecslipse limit bacterial nucleoid complexity and cell width? Synth. Syst. Biotech. 2, 267-275. doi: 10.1016/j.synbio.2017.11.004

Zhang, F., Liu, Y., Niu, X., and Zhu, Y. (2017). Efficient production of the liquid fuel 2,5-dimethylfuran from 5-hydroxymethylfurfural in the absence of acid additive over bimetallic PdAu supported on graphitized carbon.En. Fuels 31, 6364-6373. doi: 10.1021/acs.energyfuels.7b00428

Zhu, J., Wood, J., Deplanche, K., Mikheenko, I. P., and Macaskie, L. E. (2016). Selective hydrogenation using palladium bioinorganic catalyst. Appl. Catal. B Environ. 199, 108-122. doi: 10.1016/J.APCATB.2016.05.060

Zu, Y. H., Yang, P. P., Wang, J. J., Liu, X. H., Ren, J. W., Lu, G. Z., et al. (2014). Efficient production of the liquid fuel 2, 5-dimethylfuran from 5hydroxymethylfurfural over Ru/Co3O4 catalyst. Appl. Catal. B 146, 244-248. doi: 10.1016/j.apcatb.2013.04.026

Conflict of Interest Statement: The authors declare that the research was conducted in the absence of any commercial or financial relationships that could be construed as a potential conflict of interest.

Copyright $\odot 2019$ Mikheenko, Gomez-Bolivar, Merroun, Macaskie, Sharma, Walker, Hand, Grail, Johnson and Orozco. This is an open-access article distributed under the terms of the Creative Commons Attribution License (CC BY). The use, distribution or reproduction in other forums is permitted, provided the original author(s) and the copyright owner(s) are credited and that the original publication in this journal is cited, in accordance with accepted academic practice. No use, distribution or reproduction is permitted which does not comply with these terms. 